\title{
Genome sequencing of two Neorhizobium galegae strains reveals a noeT gene responsible for the unusual acetylation of the nodulation factors
}

\author{
Janina Österman ${ }^{1,3,5}$, Joanne Marsh ${ }^{6}$, Pia K Laine ${ }^{2}$, Zhen Zeng ${ }^{1}$, Edward Alatalo², John T Sullivan ${ }^{4}$, J Peter W Young ${ }^{5}$,
} Jane Thomas-Oates ${ }^{6,7}$, Lars Paulin ${ }^{2}$ and Kristina Lindström ${ }^{1,3^{*}}$

\begin{abstract}
Background: The species Neorhizobium galegae comprises two symbiovars that induce nodules on Galega plants. Strains of both symbiovars, orientalis and officinalis, induce nodules on the same plant species, but fix nitrogen only in their own host species. The mechanism behind this strict host specificity is not yet known. In this study, genome sequences of representatives of the two symbiovars were produced, providing new material for studying properties of $\mathrm{N}$. galegae, with a special interest in genomic differences that may play a role in host specificity.

Results: The genome sequences confirmed that the two representative strains are much alike at a whole-genome level. Analysis of orthologous genes showed that N. galegae has a higher number of orthologs shared with Rhizobium than with Agrobacterium. The symbiosis plasmid of strain HAMBI 1141 was shown to transfer by conjugation under optimal conditions. In addition, both sequenced strains have an acetyltransferase gene which was shown to modify the Nod factor on the residue adjacent to the non-reducing-terminal residue. The working hypothesis that this gene is of major importance in directing host specificity of $\mathrm{N}$. galegae could not, however, be confirmed.

Conclusions: Strains of N. galegae have many genes differentiating them from strains of Agrobacterium, Rhizobium and Sinorhizobium. However, the mechanism behind their ecological difference is not evident. Although the final determinant for the strict host specificity of $\mathrm{N}$. galegae remains to be identified, the gene responsible for the species-specific acetylation of the Nod factors was identified in this study. We propose the name noeT for this gene to reflect its role in symbiosis.
\end{abstract}

Keywords: Neorhizobium galegae, Genome, Nod factor, noeT, Orthologs, Mass spectrometry, Conjugative plasmid

\section{Background}

Genome sequencing has become an important tool for studying microbial properties, shedding light on phenotypes specific to different strains and environments as well as on evolutionary patterns. Genome sequences give researchers the opportunity to study genetic traits in a broader context, providing more information and the possibility to detect new linkages. The $\alpha$-proteobacterial species Neorhizobium galegae is a plant root-nodulating nitrogen-fixing bacterium which is interesting in several ways. It was described by Lindström in 1989 [1] as

\footnotetext{
* Correspondence: kristina.lindstrom@helsinki.fi

'Department of Food and Environmental Sciences, University of Helsinki, Viikinkaari 9, 00790 Helsinki, Finland

${ }^{3}$ Department of Environmental Sciences, University of Helsinki, Viikinkaari 2a, 00790 Helsinki, Finland

Full list of author information is available at the end of the article
}

Rhizobium galegae and renamed by Mousavi et al. in 2014 [2]. Phylogenetically, N. galegae differs from many of the well-known Rhizobium species, being more closely related to Agrobacterium than are many other nitrogen-fixing bacteria (e.g. [3,4]). The best-studied strains of $N$. galegae are those nodulating plants in the genus Galega: G. orientalis Lam. and G. officinalis L. These strains are very host specific, forming effective nodules only on the aforementioned Galega species. The former species Rhizobium galegae included only Galega-nodulating strains, whereas the new species $N$. galegae also includes strains infecting plant species from a range of legume genera, including Astragalus, Caragana, Lotus, Medicago, Sesbania and Vigna [2]. In this paper, however, we will consider only the Galega-nodulating strains. No other rhizobial species is known to induce root nodules on Galega legumes. The factors determining 
this strict host specificity of $N$. galegae have not been revealed by the information currently available, which is why a more complete set of information is needed. During the last ten years, the genomes of many strains phylogenetically related to $N$. galegae have been sequenced. This increasing amount of genomic information brings new possibilities to study not only the evolutionary relationship between these species, but also inter- and intraspecific genomic differences that can contribute to the establishment of the symbiosis and influence survival in the soil environment. The symbiotic behaviour of the Galega-nodulating strains of $N$. galegae makes this species an attractive candidate for this kind of study. These $N$. galegae strains are divided into two symbiovars (sv.) according to which one of the two host plant species they nodulate effectively [5]. Strains of both symbiovars are able to induce nodules on both G. orientalis and G. officinalis, but effective nodules are only formed on G. orientalis by sv. orientalis strains, and on G. officinalis only by sv. officinalis strains. None of the $N$. galegae strains tested so far induce nitrogen-fixing nodules on both G. orientalis and G. officinalis. The mechanism behind this strict discrimination is still unknown. However, while both symbiovars were known to induce root nodules only on Galega species, nodule formation has recently been observed on some species of Acacia (our unpublished data).

Rhizobia produce signal molecules called Nod(ulation) factors (NFs) upon induction of the nod genes. These genes are activated as a response to external signals, usually in the form of flavonoids exuded from plant roots but occasionally also by environmental factors such as high salt concentration [6]. NFs are lipochitin oligosaccharides (LCOs), consisting of a backbone of mainly three to five $\beta$-1,4-linked N-acetylglucosamine (GlcNAc) residues, with an $\mathrm{N}$-acyl group substituted on the non-reducing-terminal monosaccharide residue. Individual rhizobial species produce NFs with different chemical substituents on the GlcNAc residues, with most of these substituents being found on the reducing- and non-reducing-terminal residues. These signalling molecules are important for the establishment of a well-functioning symbiosis with legume hosts, and variations in the structure of the LCOs are known to be important for host specificity. NFs of rhizobia have been widely studied (for reviews see, for example, [7-10]) but the exact mechanisms by which the different structures are perceived by the host and the host signalling pathways they elicit, are the subject of ongoing studies. The NFs of $N$. galegae carry an acetyl substituent on the GlcNAc residue adjacent to the non-reducingterminal residue, which is an unusual, but not unique, location for substitution among the many NF structures described. This decoration was first described in 1999 [11], and it has since been hypothesized that this decoration is an important factor contributing to the strict host specificity of this species. However, to date, the gene responsible for adding the acetyl group to the LCOs has not been identified.

In order to gain access to more information that can be used to unravel the mechanism(s) that contribute to $N$. galegae host specificity, we sequenced the complete genomes of one representative each of the two symbiovars of $N$. galegae: the type strain HAMBI $540^{\mathrm{T}}$ [EMBL: HG938353-HG938354], representing sv. orientalis, and strain HAMBI 1141 [EMBL:HG938355-HG938357], a representative strain of $\mathrm{sv}$. officinalis. In the present study, the $N$. galegae genome sequences were compared to each other, to complete genomes of other rhizobial species and a representative of the genus Agrobacterium. The aim was to determine the degree of divergence between the symbiovars and the overall genetic similarity of $N$. galegae to closely related species, and to reveal and investigate differences that might play a role in nodulation specificity. Analysis of the genomic region containing the symbiotic nod, nif and fix genes of $N$. galegae revealed a previously unknown gene, potentially responsible for $O$ acetylation of the Nod factor. In order to demonstrate the function of this gene, which we call noeT, a deletion mutant was constructed. The structures of NFs produced by this mutant strain and its wild type parental strain were studied by mass spectrometry, and plant inoculation tests were performed to study the impact of the mutation on nodulation and nitrogen fixation. The genome sequences also revealed two sets of genes involved in conjugational transfer on the replicons of strain HAMBI 1141. Experiments were performed to find out if the plasmid containing the symbiosis genes is conjugative.

\section{Results}

\section{General features of the genomes of HAMBI $540^{\top}$ and HAMBI 1141}

Essential information on the genomes of $N$. galegae strains HAMBI $540^{\mathrm{T}}$ and HAMBI 1141 is presented in Table 1. In addition to the chromosomes, both strains harbour large megaplasmids (HAMBI $540^{\mathrm{T}} 1.81 \mathrm{Mb}, \mathrm{HAMBI}$ $11411.64 \mathrm{Mb}$ ) which have (i) plasmid-type $\operatorname{rep} A B C$ replication systems, (ii) a $\mathrm{G}+\mathrm{C}$ composition within $1 \%$ of the host's chromosome and (iii) orthologues of chromosomally located core genes in other species, even when the search criteria included a cut-off threshold as high as $70 \%$ amino acid identity over practically the whole protein sequence. Thus, the features of these megaplasmids fulfil the chromid criteria [12] and, hence, hereafter will be called chromids. The HAMBI $540^{\mathrm{T}}$ genome consists of only two replicons, while HAMBI 1141 possesses a third replicon which is a $175 \mathrm{~kb}$ plasmid. Surprisingly, the symbiosis genes of strain HAMBI 1141 are located on this small plasmid, not on the chromid. Codon usage analysis showed that both $N$. galegae strains use all 64 codons, 


\begin{tabular}{|c|c|c|c|c|}
\hline \multirow[b]{2}{*}{ Total size } & \multirow[t]{2}{*}{ HAMBI $540^{\top}$} & \multicolumn{3}{|c|}{ HAMBI 1141} \\
\hline & & $6.45 \mathrm{Mb}$ & & $6.41 \mathrm{Mb}$ \\
\hline \multirow[t]{3}{*}{ Replicons } & chromosome & $4.65 \mathrm{Mb}$ & chromosome & $4.60 \mathrm{Mb}$ \\
\hline & chromid & $1.81 \mathrm{Mb}$ & chromid & $1.64 \mathrm{Mb}$ \\
\hline & & & plasmid & $175 \mathrm{~kb}$ \\
\hline \multirow[t]{3}{*}{$\mathrm{G}+\mathrm{C}$ content $(\%)$} & chromosome & 61.5 & chromosome & 61.6 \\
\hline & chromid & 60.6 & chromid & 60.7 \\
\hline & & & plasmid & 57.5 \\
\hline Total no. of genes & 6230 & & 6213 & \\
\hline rRNA operons & 3 & & 3 & \\
\hline tRNAs & 51 & & 50 & \\
\hline
\end{tabular}

even though only 50 and 51 tRNAs were found respectively. The rate of usage of any single codon in one strain was proportional to that of the other strain. Thus, at a general level, codon usage is not remarkably different between the two genomes. Figure 1 shows the genomes as circular representations of each replicon.

\section{Genomic variability among strains of Neorhizobium, Rhizobium, Sinorhizobium and Agrobacterium}

The two N. galegae genomes were compared to three related species at the protein level through analysis of orthologous genes. The strains used in this analysis were model strains of the genera Rhizobium, Sinorhizobium (syn. Ensifer) and Agrobacterium. There were 2523 ortholog groups shared by all five strains. These groups contained 2608 genes of $N$. galegae HAMBI $540^{\mathrm{T}}$ and HAMBI 1141 each, 2614 genes of $R$. leguminosarum sv. viciae 3841, 2693 genes of S. meliloti 1021 and 2651 genes of A. fabrum C58. Analysis of inter-specific ortholog groups in relation to reference strain proteome size showed that $N$. galegae shares the most orthologs with $R$. leguminosarum sv. viciae 3841 (403 ortholog groups shared by the three strains, containing 425 genes of strain 3841 , i.e. $5.9 \%$ of its proteome size, Figure 2). The smallest number of interspecific ortholog groups was found with S. meliloti 1021 (3.5\%). Moreover, there were 365 ortholog groups where all strains but $A$. fabrum C58 were represented. Compared to 209 ortholog groups shared by the two $N$. galegae strains and A. fabrum C58, this analysis indicates that $N$. galegae has more in common with the strains representing the rhizobial species examined than it has with $A$. fabrum C58. The analysis also showed that S. meliloti 1021 seems more closely related to $N$. galegae HAMBI 1141 than to HAMBI $540^{\mathrm{T}}$. S. meliloti 1021 has twice as many pairwise ortholog groups shared with HAMBI 1141 compared to the number of orthologs shared with HAMBI $540^{\mathrm{T}}$ (58 compared to 29, Figure 2). In contrast, a proportional number of ortholog groups are shared when $R$. leguminosarum
Sv. viciae 3841 or A. fabrum C58 is compared to N. galegae HAMBI 1141 and HAMBI 540 ${ }^{\mathrm{T}}$.

Those genes identified as singletons (i.e. genes not assigned to any ortholog group) in the $N$. galegae strains after OrthoMCL analysis, were distributed over the whole genome (see Additional file 1: Figure S2). A majority of singletons identified were genes not assigned to any COG category. In both strains, genes involved in amino acid transport and metabolism were much more abundant among singletons on the chromids than on the chromosomes. In addition, singletons involved in transcription and inorganic ion transport and metabolism were overrepresented on the chromid of HAMBI $540^{\mathrm{T}}$ compared to singletons on its chromosome. Analysis of the genomic location of genes from $N$. galegae-specific ortholog groups (i.e. the 904 groups present in both $N$. galegae strains but not the other species, Figure 2), showed that these genes had largely syntenic locations in the two strains (see Additional file 1: Figure S3).

The genome nucleotide sequences of $N$. galegae HAMBI 1141 and HAMBI $540^{\mathrm{T}}$ were aligned to provide an overall picture of the synteny between the two genomes (Figure 3). The chromosome sequences were highly syntenic and only relatively short chromosomal regions unique to each strain were apparent. The chromids also have a degree of shared synteny, but regions where genetic rearrangements have occurred and regions lacking obvious homology comprise a considerable proportion of these replicons. Aside from the symbiosis genes, there is not much homology found between the $175 \mathrm{~kb}$ plasmid of HAMBI 1141 and the chromid of HAMBI $540^{\mathrm{T}}$.

In order to further analyse the structural variability between the two $N$. galegae genomes and related rhizobial strains, alignments to complete genomes of $R$. leguminosarum, $R$. tropici, S. medicae and S. meliloti were generated (Figure 4). This analysis confirmed that, among these strains, $N$. galegae is most closely related to $R$. leguminosarum. Generally, chromosomes among these strains have a fairly high shared synteny, while the $N$. galegae chromids (pHAMBI540a and pHAMBI1141a) contain genetic fragments dispersed throughout the reference genomes at a much higher frequency. A majority of these chromids do, however, consist of genetic regions with no detectable similarity to the reference genomes. The plasmid pHAMBI1141b has a very limited number of regions with similarity to regions on the reference genomes. There is clearly more similarity with regions on the two Rhizobium genomes (11 and 21 matches to $R$. leguminosarum and $R$. tropici respectively) than there is with the Sinorhizobium genomes (3 matches to $S$. medicae, none to $S$. meliloti). However, among the 21 matches to the $R$. tropici genome, 13 matches correspond to a single region on pHAMBI1141b; a probable transposase gene region. The total length of the pHAMBI1141b 


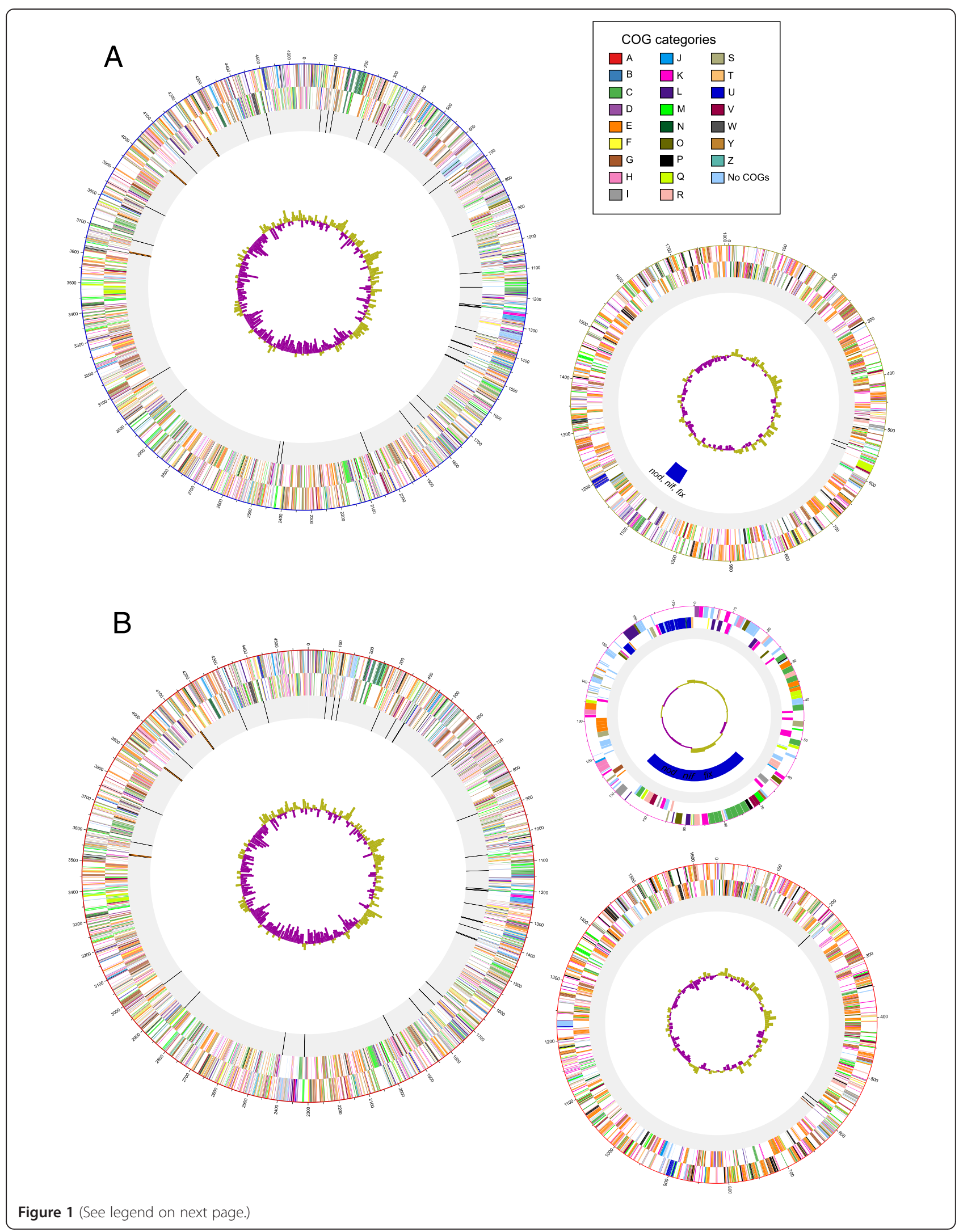


(See figure on previous page.)

Figure 1 Circular representation of the sequenced genomes. A) N. galegae sv. orientalis HAMBI $540^{\top}$ B) N. galegae sV. officinalis HAMBI 1141 . The circles represent, from outer to inner, CDSs on the forward strand, reverse strand, rRNA (purple) and tRNA (orange) genes on grey background, sym genes marked with blue on the replicons that contain these, and GC-skew. The CDSs are coloured according to the COG category they are assigned to (colour key in upper right corner of the figure).

regions having a match on the $R$. tropici genome is only $24 \mathrm{~kb}$ (out of the whole $175 \mathrm{~kb}$ plasmid). Most parts of the plasmid did not show homology to other rhizobial or agrobacterial plasmids when aligned to plasmids of 11 rhizobial strains from the genera Rhizobium, Sinorhizobium and Mesorhizobium (R. leguminosarum sv. viciae 3841, $R$. leguminosarum sv. trifolii WSM2304, $R$. tropici CIAT 899, R. phaseoli CIAT 652, $R$. etli sv. mimosae str. Mim1, R. etli CFN 42, S. fredii NGR234, S. meliloti 1021, S. medicae WSM419, M. ciceri sv. biserrulae WSM1271, R. rhizogenes K84) and A. fabrum C58. When megablast was used to search for similarities of the pHAMBI1141b plasmid to sequences in the NCBI nr database, the replicon generating the highest similarity (in terms of summed up alignment lengths) was pRtrCIAT899b of $R$. tropici CIAT 899 (a total of $25 \mathrm{~kb}$ matching sequence).

The RepABC proteins of the same strains that were used for alignment with the plasmid pHAMBI1141b were also used for analysis of the evolution of the chromids and plasmid in the two $N$. galegae strains. The evolutionary history was inferred by a Maximum Likelihood phylogeny (Additional file 1: Figure S1). The analysis showed that the replication systems of the two $N$. galegae chromids are very similar, but not very closely related to any of the other replicons analysed. The replication system of the plasmid pHAMBI1141b is different from the corresponding system on the chromid, closely related to especially plasmid pRtrCIAT899c of $R$. tropici CIAT 899, but also to plasmid pC58At of A. fabrum C58. However, the relatedness of the replication systems does not reflect the overall similarity between these plasmids.

\section{Genomic features related to the ecology of $N$. galegae}

Genes that are interesting with regard to ecological interactions of rhizobia include genes related to polysaccharide production, denitrification, pilus formation and conjugation. Rhizobial surface polysaccharides have been proven important for symbiosis-related functions. In N. galegae, genes for exopolysaccharide production, namely succinoglycan (EPS I) production, similar to those found in $S$.

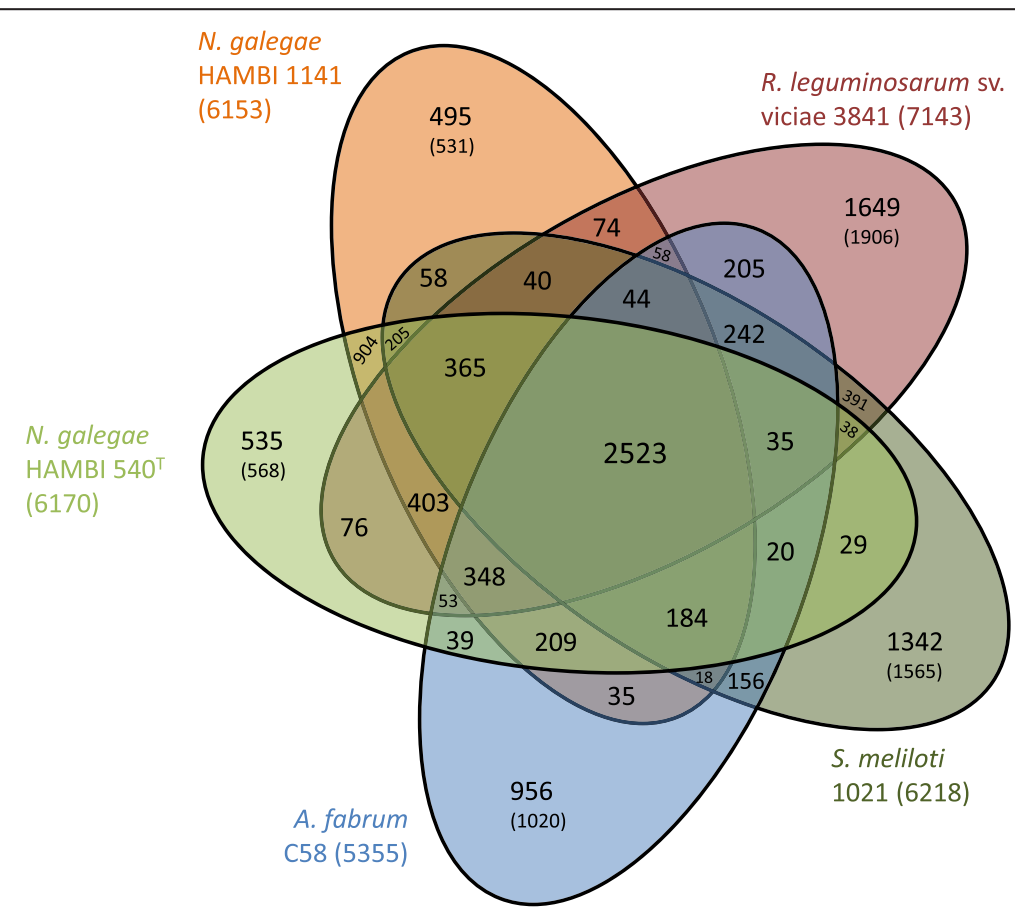

Figure 2 Illustration of the results from the OrthoMCL analysis with five genomes. Each strain has its own colour and an indication of the total number of protein-coding genes indicated in parenthesis next to the strain name. The number in the middle is the number of ortholog groups shared by all five strains. The number of singletons (i.e. genes for which no orthologous gene was found) is indicated for each strain, with the number in parenthesis indicating the total number of strain-specific genes (singletons defined by OrthoMCL together with the genes from ortholog groups consisting of multiple genes from one strain only). 


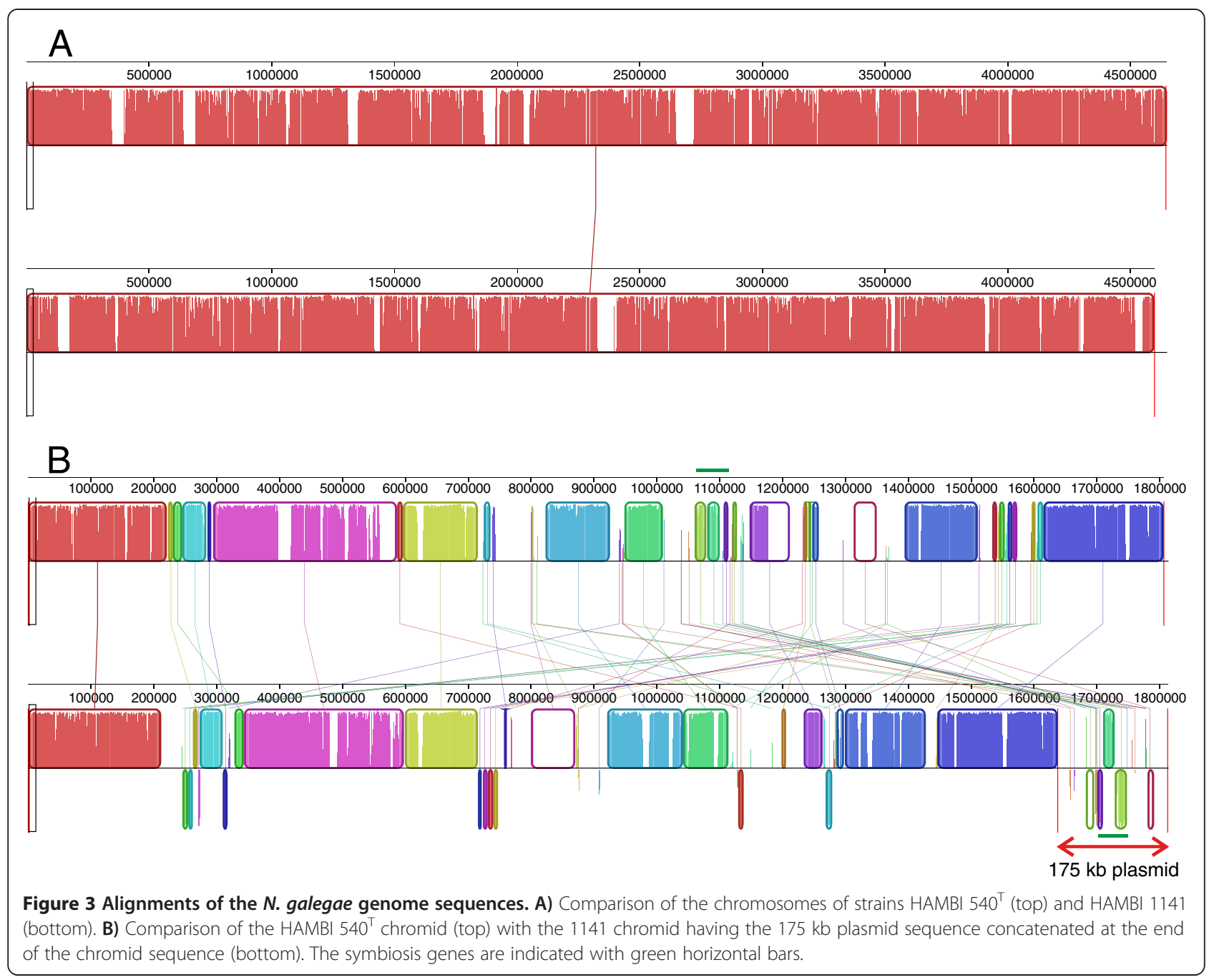

meliloti [13], are present (RG1141_CH33450-CH33590, RG540_CH34270-CH34410). However, in contrast to the gene organisation in S.meliloti, the exoT, exol, and exoZ genes were not found in $N$. galegae. An exoB gene was found distantly from the other exo genes (RG1141 CH28070, RG540_CH28720). A possible exoR regulator gene was also detected (RG1141_CH14030, RG540_ $\mathrm{CH} 14810)$. A gene cluster homologous to the acpXLlpxM(msbB) gene cluster of $S$. meliloti [14], responsible for biosynthesis and incorporation of the acyl chain substituent of lipid A in the lipopolysaccharide (LPS), is also present in N. galegae (RG1141_CH19440-CH19390, RG540_CH20240-CH20190), as well as other genes involved in lipid A biosynthesis, namely a bamA-lpxD-fabZlpxA-lpxI-lpxB gene cluster (RG1141_CH15400- CH154 50, RG540_CH15850-CH15900) and an lpxK-like gene (RG1141_CH04800, RG540_CH04440). Genes involved in LPS core oligosaccharide synthesis are also present on the chromosome: greA-lpsB (RG1141_CH24690-CH24700, RG540_CH24720- CH24750), lpsE (RG1141_CH24710,
RG540_CH24760), a glycosyl transferase (RG1141_CH247 20, RG540_CH24770) and an lrp gene (RG1141_CH24 730, RG540_CH24780). Genes responsible for capsular polysaccharide (KPS) synthesis, export and polymerization in $N$. galegae could not be pinpointed based on sequence homology to known rhizobial $r k p-1, r k p-2$ and $r k p-3$ region genes. Even though strains of $N$. galegae have been shown to produce LPS containing different $\mathrm{O}$-antigen chains [15], no genes for O-antigen transport (wzm and $w z t$ ) could be detected in either $N$. galegae strain.

In addition to polysaccharide production, interaction between bacteria and plants can be enhanced by extracellular structures like the Flp/Tad pilus, which has been proposed to play a possible role in virulence of the potato pathogen Pectobacterium [16]. Annotation revealed some tad genes (RG1141_CH43400, RG1141_CH43410, RG1141_CH43500, RG1141_CH43510, RG540_CH437 90, RG540_CH43800, RG540_CH43890, RG540_CH439 00, RG540_CH10650, RG540_CH10660) on the chromosome of $N$. galegae, even though no two-component 


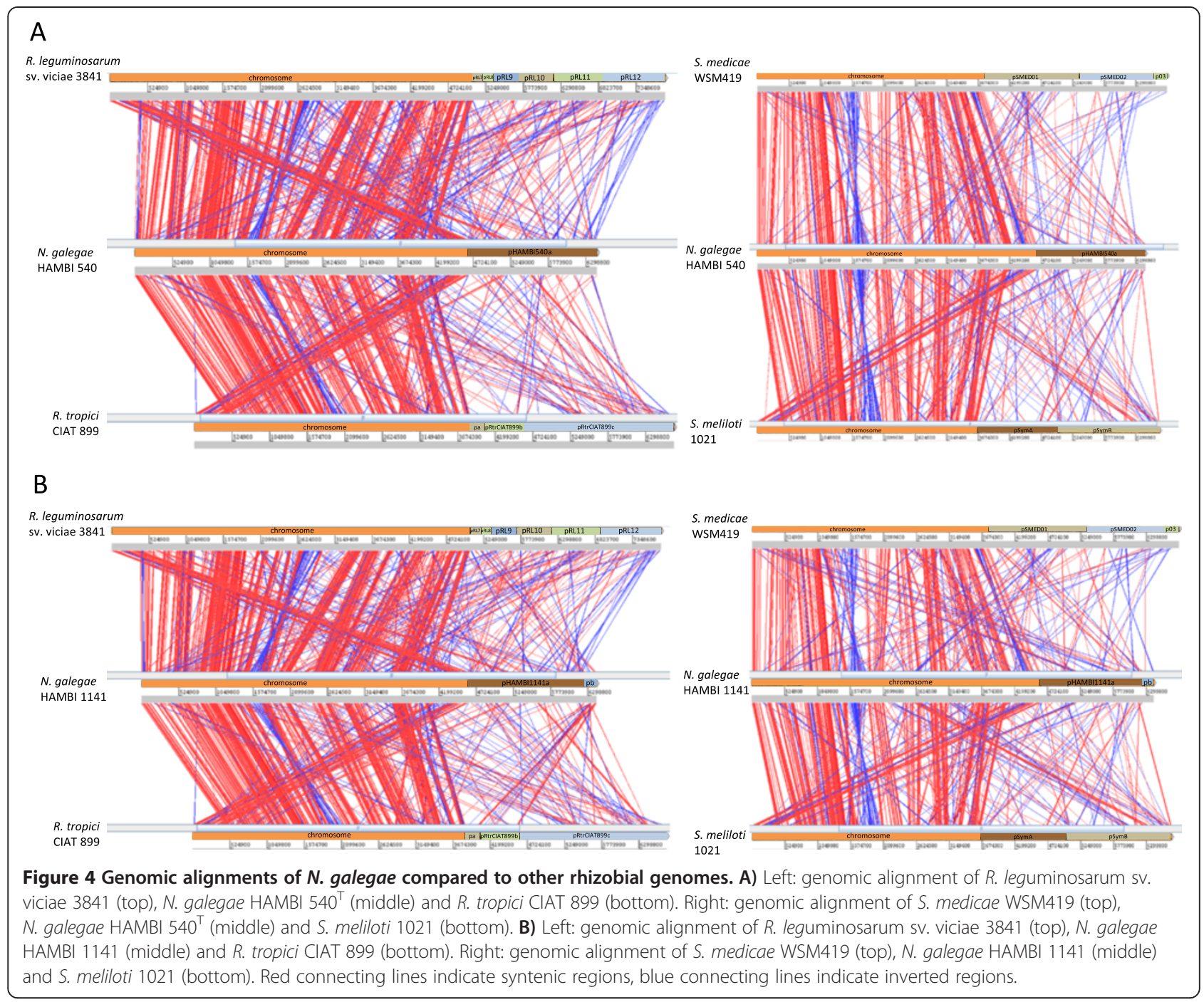

system like that one found in Pectobacterium could be detected in the vicinity of these genes. In addition, the similarity of the tad genes of $N$. galegae to those of Pectobacterium is very limited. Nonetheless, based on blastx results, gene regions similar to that in $N$. galegae seem to be common in rhizobial relatives.

Even though rhizobia are known for their ability to fix nitrogen, some strains have genes encoding functions in the denitrification pathway. The only rhizobia shown to be true denitrifiers belong to the genus Bradyrhizobium, but partial denitrification pathways have also been found in species belonging to other genera [17-19]. Denitrification functions are encoded by the nap, nir, nor and nos gene clusters. In $N$. galegae strains HAMBI $540^{\mathrm{T}}$ and HAMBI 1141, the nirKV (RG1141_CH34420-CH34410, RG540_CH35240-CH35230) and norECBQD (RG1141_ CH34790-CH34840, RG540_CH35550-CH35600) genes (as well as a putative norF between norE and norC) are present, encoding nitrite and nitric oxide reductase respectively. However, no genes for nitrate reductase or nitrous oxide reductase have been detected.

An important part of the genomic differences between the sequenced strains is made up of two gene regions encoding putative type IV secretion systems (T4SS). Genes coding for a type IVB rhizobial plasmid conjugation system [20] are located on the chromid of strain HAMBI 1141 (Mfp component RG1141_PA08510-PA08620, Dtr component RG1141_PA08710-PA08730) while a type I conjugation system (Mfp component and QS regulation genes RG1141_PB01500-PB01560, Dtr component RG1141_PB01600-PB01730) is found on the symbiosis plasmid. The traI/traR/traM quorum sensing regulation system is present on the plasmid pHAMBI1141b together with what seems to be a complete set of genes required for a functional T4SS system. Experimental work showed that strain HAMBI 1141 is able to transfer its symbiosis plasmid through conjugation. Plant tests and plasmid profile investigation by a modified Eckhardt gel procedure 
confirmed that conjug transfer of the plasmid carrying the symbiosis gene region in strain HAMBI 1207 (streptomycin-resistant derivative of HAMBI 1141) occurred when the nodulation-defective strain HAMBI 1587 ( $N$. galegae sv. orientalis), was mated with strain HAMBI 1207. These transconjugants formed effective nodules on G. officinalis, indicating that all genes needed for nitrogen fixation on G. officinalis were transferred to strain HAMBI 1587. The other genes present in strain HAMBI 1587 did not interfer with symbiosis on G. officinalis. On the other hand, the same transconjugants formed effective nodules on G. orientalis only sporadically. This observation indicates that even though the nodulation defect was complemented by the nod genes on the conjugated plasmid, some of the genes present on this same plasmid interfere with the symbiotic functions on G. orientalis.

To further investigate whether the T4SS genes on the chromid of the same strain were involved in transfer of the symbiosis plasmid, a deletion mutant of HAMBI 1141 lacking the defined putative T4SS genes on the chromid (HAMBI 3490), was constructed using a Cre-loxP-based technique. Two lox sites were inserted flanking the target region, which was then excised from the chromid by the Cre protein introduced on a separate vector. When conjugation was attempted between HAMBI 3490 and HAMBI 1587 , no nodules could be observed on the inoculated $G$. orientalis plants, indicating that the chromid-borne T4SS genes are required to mobilise the symbiosis plasmid. To further investigate this hypothesis, a plasmid-cured derivative of strain HAMBI 1207 (assigned HAMBI 3489) was constructed using random transposon mutagenesis of the suicide vector pMH1701 containing the $s a c B$ gene. HAMBI 3489 was conjugated with HAMBI 3490 and the wild-type HAMBI 1141 separately. Exconjugants were inoculated on G. officinalis plants to determine whether conjugal transfer of the symbiosis plasmid had taken place, thereby rendering HAMBI 3489 able to induce nodules on G. officinalis. However, no nodules could be observed on any of the inoculated plants, regardless of whether HAMBI 3489 had been mated with the wild-type or the deletion mutant of HAMBI 1141. To ensure that the results were not due to unsuccessful selection of transconjugants when streptomycin was used to select for the recipient, additional conjugation attempts were performed with a derivative of HAMBI 3489 containing a gene for gentamicin resistance (HAMBI 3491) as the recipient. HAMBI 3491 was mated with HAMBI 3490, HAMBI 3470 (HAMBI 1587 which has gained the symbiosis plasmid of HAMBI 1207) and HAMBI 1141. Plasmid profile analysis and re-inoculation tests indicated that there were no true transconjugants resulting from these matings. Taken together, all of these results indicate that the symbiosis plasmid in HAMBI 1141 is not self-transmissible, but likely needs some assistance from the T4SS genes on the chromid for transfer. In addition, conjugal transfer of the symbiosis plasmid in HAMBI 1141 does not seem to occur at a high frequency to a broad range of recpipients, since no true transconjugants could be observed when HAMBI 1141 was mated with A. fabrum strain C58C1 (cured of its Ti plasmid), S. meliloti HAMBI $1213\left(\mathrm{NodC}^{-}\right)$and R. leguminosarum sv. viciae HAMBI $1594\left(\mathrm{NodA}^{-}\right)$and exconjugants tested on G. officinalis as well as the hosts Medicago sativa (A. fabrum and S. meliloti) and Vicia villosa (R. leguminosarum).

In strain HAMBI $540^{\mathrm{T}}$, no T4SS-related genes are found. On the other hand, a type VI secretion system (T6SS) is found on the chromid of strain HAMBI $540^{\mathrm{T}}$ (RG540_PA11400-PA11590), while no corresponding secretion system can be found in strain HAMBI 1141. This T6SS comprises the 14 genes found in the imp operon of A. fabrum strain C58 as well as the three conserved genes of the $h c p$ operon; $t s s H$, tssD and tssI [21]. The T6SS of HAMBI $540^{\mathrm{T}}$ is most similar to systems found in three other rhizobial strains: $R$. etli Sv. mimosae strain Mim1 plasmid pRetMIM1f (NC_021911), R. leguminosarum sv. viciae strain 3841 plasmid pRL12 (NC_008378.1), and Rhizobium sp. BR816 scaffold 1_C5 (AQZQ01000005.1). Possible imperfect $\sigma^{54}$ and NifA binding sites were found in the upstream region of $t s s$, indicating that the T6SS might play a role in symbiosis.

\section{Symbiosis gene regions of $N$. galegae}

As can be seen in Figure 3, there are genetic rearrangements found inside the regions comprising the symbiosis genes of the two strains studied. Insertion sequences (ISs) are well represented in these regions, probably accounting for some of the rearrangements. Nevertheless, the known symbiosis genes form three blocks that are represented in the same configuration in both genomes (Figure 5). In strain HAMBI $540^{\mathrm{T}}$, these blocks are flanked by IS elements, while strain HAMBI 1141 has an IS at the right boundary only, downstream of noeT. In this strain, nodE is separated from the next transposase gene by 38 genes, some of which are also encountered in the region downstream of nodE in strain HAMBI $540^{\mathrm{T}}$. The regions downstream of the noeT gene are, however, different in the two strains. The borders of the symbiosis gene cluster are not defined, but here we concentrate on the regions that contain the known symbiosis genes. The genomic blocks assigned numbers 2 and 3 in Figure 5 are not entirely identical in the two strains. In block 2, an rpoN gene (RNA polymerase $\sigma^{54}$ ) has been inserted between nifA and nifB in HAMBI 540 ${ }^{\mathrm{T}}$. In block 3, HAMBI 1141 harbours an IS upstream of noeT, while there is no IS in this part of the region in HAMBI $540^{\mathrm{T}}$. It is worth noting that the IS elements present in the symbiosis gene regions of the two strains in this study are not highly similar. Despite 


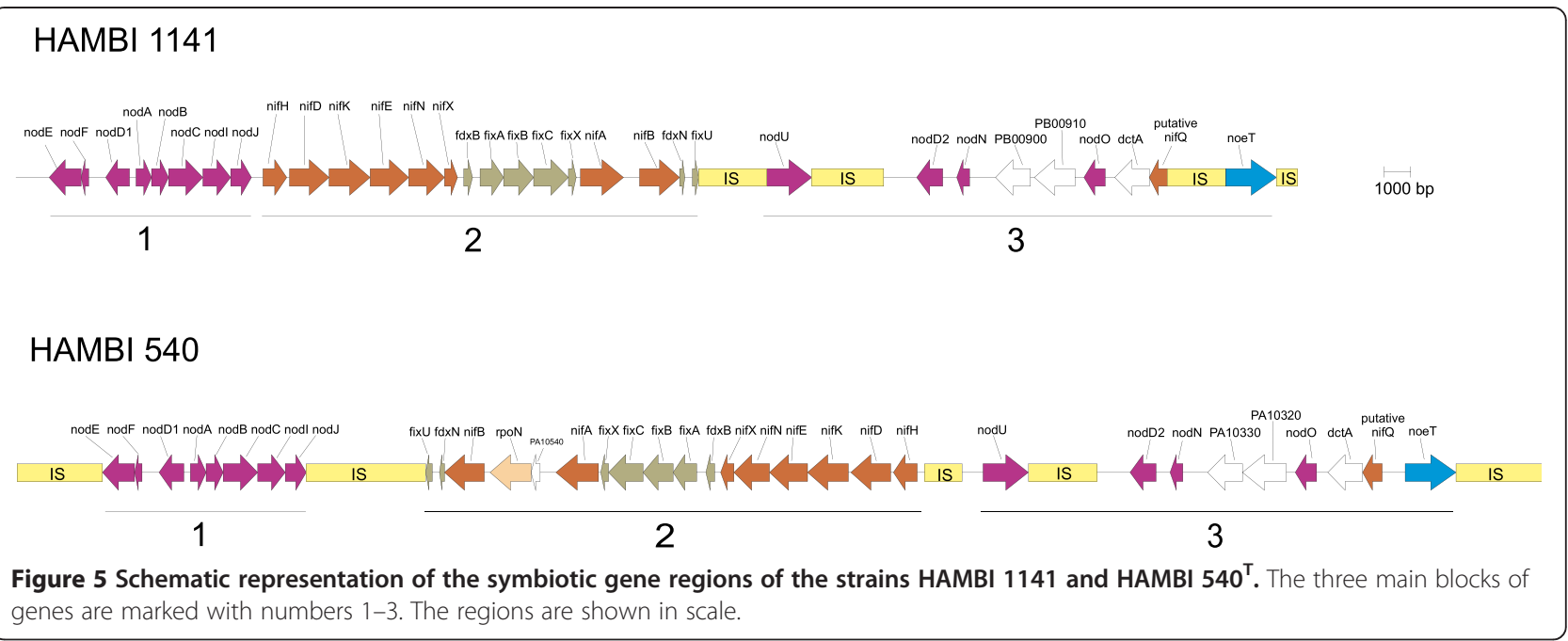

the impression of similarity of the ISs surrounding the nod $U$ gene, these regions seem unrelated.

Three genes present in the symbiosis gene regions did not at first glance seem to be involved in symbiotic events. The genes PA10320 and PA10330 of HAMBI $540^{\mathrm{T}}$ (and corresponding genes PB00910 and PB00900 in HAMBI 1141) appear to form a kind of type I secretion system (T1SS). Based on nucleotide sequence similarity the two genes were most similar to the rhizobiocin secretion system rspDE-like genes of $R$. tropici CIAT 899 [22] and $R$. leguminosarum [23], when the region containing the two genes was compared to genomic data of other rhizobia. However, the product of gene PA10320 was most similar to a PrtD family type I secretion system ATP binding cassette $(A B C)$ gene product, while the product of PA10330 was most similar to a HlyD family type I secretion system membrane fusion protein gene product. The product of the third unexpected gene, a second copy of $d c t A$, is a C4dicarboxylic acid transporter protein. The putative nifQ gene upstream of it has similarity to the nifQ gene of other species, although the product has regions with very little similarity to other NifQ protein sequences. More importantly, the proposed molybdenum-binding motif $\mathrm{Cx}_{4} \mathrm{Cx}_{2}$ $\mathrm{Cx}_{5} \mathrm{C}$ [24] is not present in this protein in the two $N$. galegae strains.

Analysis of nonsynonymous/synonymous substitution rate ratio was performed for the genes in the symbiosis gene region (Figure 6) in a pairwise manner, comparing the genes of the two sequenced strains. Averaging over the whole gene, a $d_{\mathrm{N}} / d_{\mathrm{S}}<1$ was obtained for most genes, indicating fairly strong purifying selection (Figure 6). However, the putative nifQ gene had a non-synonymous substitution rate that was much higher than for any other gene, and much higher than the synonymous substitution rate of the same gene, making this gene a factor of interest. An analysis of variable selective pressure acting on different branches of the NifQ phylogeny of rhizobial species (Additional file 1: Figure S4) was performed to investigate whether $N$. galegae nifQ has changed under positive selection. The estimate of $\omega$ under the null hypothesis, as an average over the phylogeny, was 0.25 , indicating that evolution of nifQ was dominated by purifying selection. The likelihood ratio test (LRT) suggests that selective pressure (0.26) on the branch separating the $N$. galegae symbiovars from their closest neighbour (S. fredii) in the ML tree, was not significantly different from the average over the other branches. Hence, there is no evidence for functional divergence of nifQ of $N$. galegae compared to the others, by positive selection. When testing the hypothesis that the divergence of $N$. galegae nifQ was due to an increase in the non-synonymous substitution rate over all lineages of $N$. galegae, the LRT was highly significant $(\mathrm{P}<$ 0.0001 ), and the parameter estimates for $N$. galegae nifQ indicated an increase in the relative rate of nonsynonymous substitution by a factor of 3 . These results indicate that the non-synonymous rate increased in $N$. galegae nifQ following divergence from other rhizobial species, even though it seems to have occurred through an increase in the mutation rate rather than by positive selection. The function of nifQ in N. galegae has not been investigated to date.

\section{noeT is involved in Nod factor biosynthesis}

The whole-genome sequence analysis confirmed previous work on the $N$. galegae symbiosis gene region $[25,26]$, and enabled an extended analysis of this region. As a result, a previously undiscovered putative nodulation gene, preceded by a nod-box sequence, was identified at the rightmost end (according to the arrangement in Figure 5). Homology searches performed using NCBI BLAST suggested that this gene was a putative acetyltransferase gene, the closest homolog (95\% and 96\% amino acid identity 


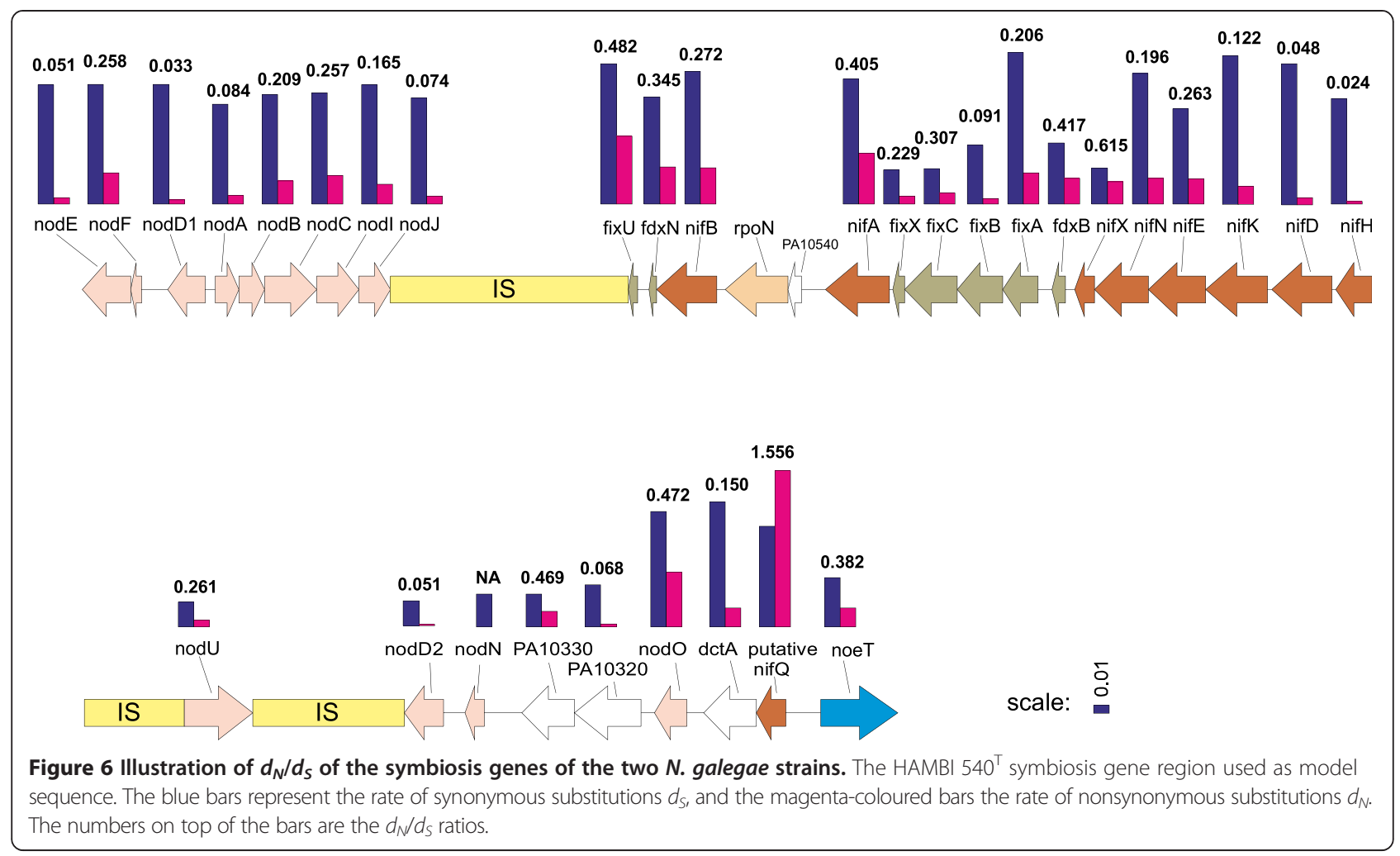

with the HAMBI 1141 and HAMBI $540^{\mathrm{T}}$ proteins respectively) being a gene called $h s n T$ (host specific nodulation gene $T$ ) in R. leguminosarum sv. trifolii ICC105 (accession number EU919402). The Nod factors of N. galegae have been shown to have an unusual acetyl substituent on the GlcNAc residue adjacent to the non-reducing-terminal residue, but the gene responsible for this modification had not been determined. Thus, we suspected that this gene could be responsible for adding this decoration and hence, we named this gene noeT.

To investigate whether the noeT gene has an impact on symbiosis, a mutant was constructed in strain HAMBI 1174. $\left(\mathrm{Sm} / \mathrm{Spc}\right.$ resistant derivative strain of HAMBI $\left.540^{\mathrm{T}}\right)$ background where this gene was replaced by the $\Omega-\mathrm{Km}$ interposon. When the mutant strain (HAMBI 3275) was inoculated on G. orientalis, nodules were formed at the same rate as for the wild-type strain during the first 16 days post-inoculation. After 16 days, new nodules continued to be formed by the wild-type, whereas the number of nodules formed by the mutant increased only slightly (Figure 7). At 40 days post-inoculation, the average number of nodules formed per plant was significantly different between plants inoculated with HAMBI 1174 and HAMBI 3275 at $40 \mathrm{dpi}(\mathrm{U}=103.500, \mathrm{z}=-2.450, \mathrm{p}=0.014)$. Because of the growth-limiting test conditions, not all nodules were obviously effective (large and pink). However, the proportion of effective nodules formed (average number of effective nodules compared to total number of nodules) per plant was the same for plants inoculated with either of the strains at $17 \mathrm{dpi}(0.6)$, but differed at $40 \mathrm{dpi}$ (0.7 for HAMBI 1174 and 0.9 for HAMBI 3275). When the mutant strain was tested on Trifolium repens, Pisum sativum cv. Afghanistan, Phaseolus vulgaris, Vicia hirsuta and Astragalus sinicus, no nodules were observed, as was the case when these plants were inoculated with the wildtype. Ineffective nodules were induced on G. officinalis.

The plant tests showed that the mutation did not affect the ability of the bacterium to induce nodules on Galega plants nor to fix nitrogen inside the nodules of G. orientalis. Nevertheless, the mutation had an impact on the number of nodules formed as time passed. In order to determine the function of the noeT gene, cultures of wild type $R$ galegae strain HAMBI 1174 and its noeT mutant HAMBI 3275 were generated for LCO isolation and structural analysis. The NF extracts were fractionated using solid phase extraction (SPE) with $45 \%$ and $60 \%$ acetonitrile solutions. The RP-HPLC profiles of the $45 \%$ and $60 \%$ SPE fractions from the wild type and mutant strain crude Nod factor extracts showed major peaks of UV absorbance for fractions eluting between 40-50 minutes (Additional file 1: Figure S5, regions marked 2 and 3), which have previously been shown to correspond to the elution position of LCOs [27]. In the chromatogram of the $45 \%$ SPE fraction, these peaks are dwarfed by a very strongly absorbing peak, on MS analysis shown to be a polymeric contaminant eluting 


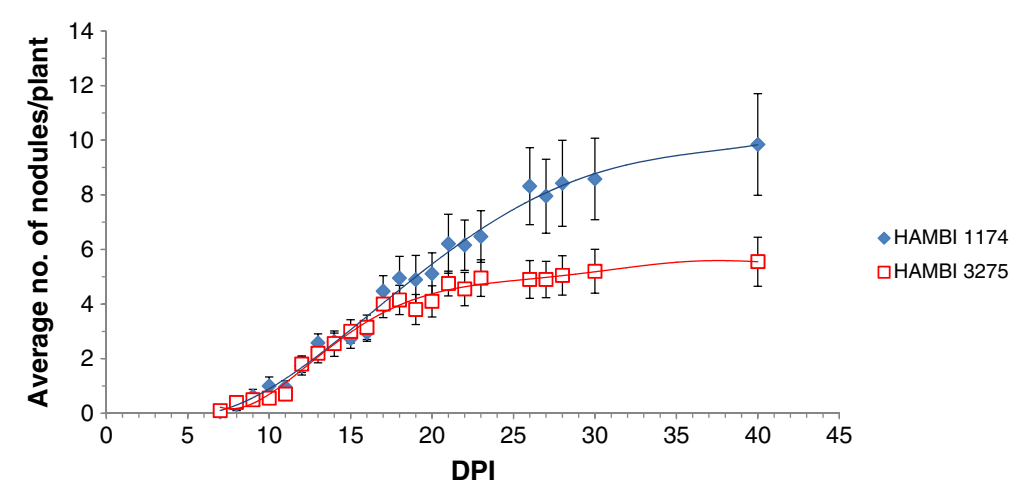

Figure 7 Average number of nodules observed on G. orientalis plants after inoculation. Nineteen plants inoculated with wild-type N. galegae HAMBI 1174 and twenty plants inoculated with its noeT mutant HAMBI 3275 were scored for nodules present between 7 and $40 \mathrm{dpi}$. Error bars represent standard error.

between 30 and 40 minutes (Additional file 1: Figure S5, region marked 1). HPLC fractions from the fractionation of the 45 and $60 \%$ SPE fractions of the culture filtrate from wild type and noeT mutant $N$. galegae HAMBI 1174 were analysed using ESI-MS and MALDI-MS and collision-induced dissociation (CID) product ion analysis, to determine LCO structures. In fractions eluting between 40-52 minutes, giving rise to strong UV absorbance at $203 \mathrm{~nm}$ (Additional file 1: Figure S5), peaks corresponding to $[\mathrm{M}+\mathrm{H}]^{+}$and $[\mathrm{M}+\mathrm{Na}]^{+}$were observed.

The wild type strain gave LCO-derived $[\mathrm{M}+\mathrm{H}]^{+}$peaks at $\mathrm{m} / \mathrm{z} 1134$ and 1162 along with $[\mathrm{M}+\mathrm{Na}]^{+}$peaks at $\mathrm{m} / z$ $1114,1118,1120,1134,1136,1142,1144,1146,1162,1184$, 1186, 1188 and 1190. These ions correspond in composition to $\mathrm{GlCNAc}_{4}$-containing LCOs with $\mathrm{C} 18$ or $\mathrm{C} 20$ fatty acyl chains and substituted with a carbamoyl, acetyl and exceptionally a methyl moiety (Table 2). CID was used to generate product ions that allowed structures to be assigned. Intense product ions were generated from the majority of the LCO-derived signals observed. The $m / z$ values of these fragment ions, largely arising by glycosidic bond cleavage and charge retention on the non-reducing-terminal portion (B series ions), allow determination of the fatty acyl chain present on the non-reducing-terminal residue as well as the substituents arranged on the chitin backbone. It is notable that some of the species observed from the wild type strain correspond to LCOs bearing an additional moiety that adds $42 \mathrm{Da}$, which would correspond to the presence of an acetyl moiety. One of the major LCOs from $N$. galegae HAMBI 1174 resulting in intense mass spectrometric signals $([\mathrm{M}+$ $\mathrm{H}^{+}$at $m / z$ 1162) gave product ions at $m / z 941,738$ and 493 (Additional file 1: Figure S6) consistent with B-ions for a $\mathrm{GlCNAc}_{4}$ species containing a C20:3 fatty acid chain, a carbamoyl group on the non-reducing-terminal residue, and an acetyl moiety present on the GlcNAc unit adjacent to the non-reducing-terminal residue. In addition, fragment ions were observed $60 \mathrm{~m} / z$ units below the precursor $(-60$ at $m / z$ 1102), the $\mathrm{B}_{3}$ ion $\left(-60\right.$ at $m / z$ 881) and the $\mathrm{B}_{2}$ ion
(-60 at $m / z 678$ ), corresponding to the elimination of the acetyl group as neutral acetic acid.

Similar ESI- and MALDI-MS analyses of the HPLC fractions obtained on purification of the LCOs from the noeT mutant strain HAMBI 3275 , exhibited $[\mathrm{M}+\mathrm{H}]^{+}$peaks at $m / z 1096,1098,1120$ and 1122 along with $[\mathrm{M}+\mathrm{Na}]^{+}$ peaks at $m / z 1092,1114,1116,1118,1120,1142,1144$, 1146, 1148, 1160, 1162, 1164 and 1172 (Table 2). While intense signals were obtained for the LCOs from the mutant strain HAMBI 3275, none of the species corresponds to an acetyl-bearing LCO. One of the most intense ions observed on analysis of the noeT mutant strain was at $\mathrm{m} / \mathrm{z}$ $1118\left([\mathrm{M}+\mathrm{Na}]^{+}\right)$, which fragments to give $B_{1}, B_{2}$ and $B_{3}$ ions at $m / z 491,694$ and 987 respectively (Additional file 1: Figure S7); the $m / z$ increment between the $B_{1}$ and $B_{2}$ ions is 203 (for this and all the mutant strain LCOs), corresponding to a GlcNAc residue without the additional acetyl moiety, and there was no evidence in any of the product ion spectra for the loss of acetic acid, seen so clearly in the spectra of the acetylated LCOs from the wild type strain (Additional file 1: Figure S6). The $\mathrm{B}_{1}$ ion at $\mathrm{m} / z$ 491 corresponds to the presence of a carbamoyl moiety and a C18:1 acyl chain on the non-reducing-terminal residue. From these data, it is evident that the wild type $N$. galegae produces LCOs that bear an acetyl residue on the GlcNAc residue adjacent to the non-reducing residue and that this acetyl group is absent from the LCOs produced by the noeT mutant. The nature of the acetyl linkage was demonstrated by treatment of O-acetylated LCOcontaining HPLC fractions with mild basic conditions which cleave ester linkages. MALDI-MS analysis of the HPLC fractions following base treatment revealed a reduction of $42 \mathrm{~m} / \mathrm{z}$ units of the protonated and sodiated molecules, and, on product ion analysis, from the relevant fragment ions (Table 3). The data are consistent with the removal, on mild base treatment, of an ester-linked acetyl moiety from the residue adjacent to the non-reducing terminus, whilst the amide-bound fatty acid remained in 
Table 2 Summary of the mass spectrometric data from the LCOs in $45 \%$ and $60 \%$ SPE fractions

\begin{tabular}{|c|c|c|c|}
\hline Parent ion & Molecular species & Fragment ions & Structure assignment \\
\hline \multicolumn{4}{|c|}{ HAMBI 1174} \\
\hline 1114 & {$[\mathrm{M}+\mathrm{Na}]^{+}$} & $487,690,893$ & $\operatorname{IV}(\mathrm{C} 18: 3, \mathrm{Cb})$ \\
\hline 1118 & {$[\mathrm{M}+\mathrm{Na}]^{+}$} & $491,694,897$ & IV(C18:1, Cb) \\
\hline 1120 & {$[\mathrm{M}+\mathrm{Na}]^{+}$} & $493,696,899$ & $\mathrm{IV}(\mathrm{C} 18: 0, \mathrm{Cb})$ \\
\hline 1134 & {$[\mathrm{M}+\mathrm{H}]^{+}$} & $465,710,913$ & IV(C18:3, Cb, OAc) \\
\hline 1134 & {$[\mathrm{M}+\mathrm{Na}]^{+}$} & $507,710,913$ & IV(C18:1-OH, Cb) \\
\hline 1134 & {$[\mathrm{M}+\mathrm{Na}]^{+}$} & $493,696,899$ & $\mathrm{IV}\left(\mathrm{C} 18 \mathrm{O} \mathrm{O}, \mathrm{Cb}, \mathrm{CH}_{3}\right)^{*}$ \\
\hline 1136 & {$[\mathrm{M}+\mathrm{Na}]^{+}$} & $-, 712,915$ & IV(C18:0-OH, Cb) \\
\hline 1142 & {$[\mathrm{M}+\mathrm{Na}]^{+}$} & $515,718,921$ & IV(C20:3, Cb) \\
\hline 1144 & {$[\mathrm{M}+\mathrm{Na}]^{+}$} & $517,720,923$ & IV(C20:2, Cb) \\
\hline 1146 & {$[\mathrm{M}+\mathrm{Na}]^{+}$} & $519,722,925$ & IV(C20:1, Cb) \\
\hline 1162 & {$[\mathrm{M}+\mathrm{H}]^{+}$} & $493,678,738,881,941,1102$ & IV(C20:3, Cb, OAc) \\
\hline 1162 & {$[\mathrm{M}+\mathrm{Na}]^{+}$} & $493,678,738,881,941,1102$ & $\mathrm{IV}(\mathrm{C} 18: 0, \mathrm{Cb}, \mathrm{OAc})$ \\
\hline 1162 & {$[\mathrm{M}+\mathrm{Na}]^{+}$} & $535,738,941$ & IV(C20:1-OH, Cb) \\
\hline 1184 & {$[\mathrm{M}+\mathrm{Na}]^{+}$} & $515,700,760,903,963,1124$ & IV(C20:3, Cb, OAc) \\
\hline 1186 & {$[\mathrm{M}+\mathrm{Na}]^{+}$} & $517,702,762,905,965,1126$ & IV(C20:2, Cb, OAc) \\
\hline 1188 & {$[\mathrm{M}+\mathrm{Na}]^{+}$} & $519,704,764,907,967,1128$ & IV(C20:1, Cb, OAc) \\
\hline 1190 & {$[\mathrm{M}+\mathrm{Na}]^{+}$} & $521,766,969$ & IV(C20:0, Cb, OAc) \\
\hline \multicolumn{4}{|c|}{ HAMBI 3275} \\
\hline 1092 & {$[\mathrm{M}+\mathrm{Na}]^{+}$} & $465,668,871$ & IV(C16:0, Cb) \\
\hline 1096 & {$[\mathrm{M}+\mathrm{H}]^{+}$} & $469,672,875$ & IV(C18:1, Cb) \\
\hline 1098 & {$[\mathrm{M}+\mathrm{H}]^{+}$} & $471,674,877$ & IV(C18:0, Cb) \\
\hline 1114 & {$[\mathrm{M}+\mathrm{Na}]^{+}$} & $487,690,893$ & IV(C18:3, Cb) \\
\hline 1116 & {$[\mathrm{M}+\mathrm{Na}]^{+}$} & $489,692,895$ & IV(C18:2, Cb) \\
\hline 1118 & {$[\mathrm{M}+\mathrm{Na}]^{+}$} & $491,694,897$ & IV(C18:1, Cb) \\
\hline 1120 & {$[\mathrm{M}+\mathrm{H}]^{+}$} & $493,696,899$ & IV(C20:3, Cb) \\
\hline 1120 & {$[\mathrm{M}+\mathrm{Na}]^{+}$} & $493,696,899$ & IV(C18:0, Cb) \\
\hline 1122 & {$[\mathrm{M}+\mathrm{H}]^{+}$} & $495,698,901$ & IV(C20:2, Cb) \\
\hline 1142 & {$[\mathrm{M}+\mathrm{Na}]^{+}$} & $515,718,921$ & IV(C20:3, Cb) \\
\hline 1144 & {$[\mathrm{M}+\mathrm{Na}]^{+}$} & $517,720,923$ & IV(C20:2, Cb) \\
\hline 1146 & {$[\mathrm{M}+\mathrm{Na}]^{+}$} & $519,722,925$ & IV(C20:1, Cb) \\
\hline 1148 & {$[\mathrm{M}+\mathrm{Na}]^{+}$} & $521,724,927$ & IV(C20:0, Cb) \\
\hline 1160 & {$[\mathrm{M}+\mathrm{Na}]^{+}$} & $533,736,939$ & IV(C20:2-OH, Cb) \\
\hline 1162 & {$[\mathrm{M}+\mathrm{Na}]^{+}$} & $535,738,941$ & IV(C20:1-OH, Cb) \\
\hline 1164 & {$[\mathrm{M}+\mathrm{Na}]^{+}$} & $537,740,943$ & IV(C20:0-OH, Cb) \\
\hline 1172 & {$[\mathrm{M}+\mathrm{Na}]^{+}$} & $545,748,951$ & IV(C22:2, Cb) \\
\hline
\end{tabular}

*Has methyl group on reducing terminal position.

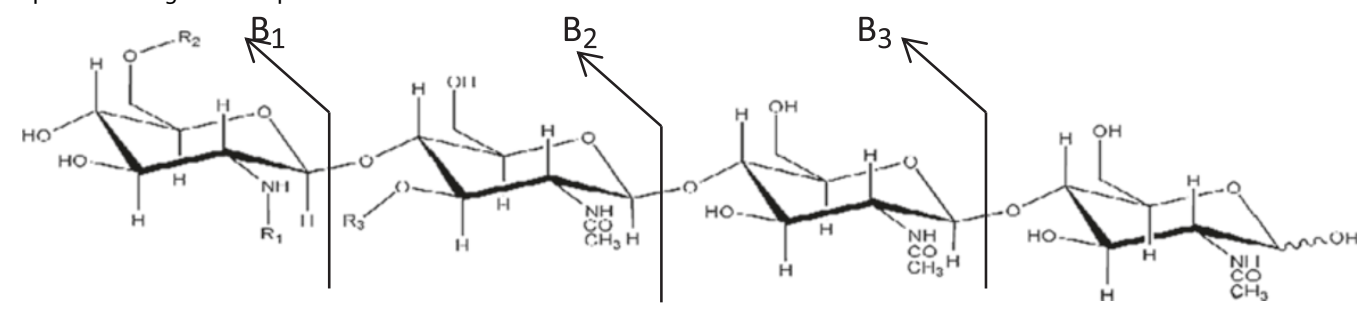


Table 3 Effects of de-O-acetylation on the LCOs of HAMBI 1174

\begin{tabular}{|c|c|c|c|c|c|c|}
\hline \multicolumn{2}{|c|}{ Precursor ion } & \multirow[b]{2}{*}{$\begin{array}{l}\text { Molecular } \\
\text { Species }\end{array}$} & \multicolumn{2}{|c|}{ Fragment lons } & \multicolumn{2}{|c|}{ Structure Assignment } \\
\hline $\begin{array}{l}\text { Before base } \\
\text { treatment }\end{array}$ & $\begin{array}{l}\text { After base } \\
\text { treatment }\end{array}$ & & $\begin{array}{l}\text { Before base } \\
\text { treatment }\end{array}$ & $\begin{array}{l}\text { After base } \\
\text { treatment }\end{array}$ & $\begin{array}{l}\text { Before base } \\
\text { treatment }\end{array}$ & $\begin{array}{l}\text { After base } \\
\text { treatment }\end{array}$ \\
\hline 1162 & 1120 & {$[\mathrm{M}+\mathrm{H}]^{+}$} & $493,678,738,881,941,1102$ & $493,696,899$ & $\mathrm{IV}(\mathrm{C} 20: 3, \mathrm{Cb}, \mathrm{OAc})$ & $\mathrm{IV}(\mathrm{C} 20: 3, \mathrm{Cb})$ \\
\hline 1184 & 1142 & {$[\mathrm{M}+\mathrm{Na}]^{+}$} & $515,700,760,903,963,1124$ & $515,718,921$ & IV(C20:3, Cb, OAc) & IV(C20:3, Cb) \\
\hline 1186 & 1144 & {$[\mathrm{M}+\mathrm{Na}]^{+}$} & $517,702,762,905,965,1126$ & $517,720,923$ & IV(C20:2, Cb, OAc) & $\mathrm{IV}(\mathrm{C} 20: 2, \mathrm{Cb})$ \\
\hline 1188 & 1146 & {$[\mathrm{M}+\mathrm{Na}]^{+}$} & $519,704,764,907,967,1128$ & $519,722,925$ & IV(C20:1, Cb, OAc) & IV(C20:1, Cb) \\
\hline
\end{tabular}

place as expected. Thus, the acetyl moiety present on the LCOs of $N$. galegae HAMBI 1174 and absent in those from the noeT mutant is shown to be ester bound.

\section{Discussion}

In this study, the genome sequences of two $N$. galegae strains is reported; the type strain HAMBI $540^{\mathrm{T}}$ (symbiovar orientalis) and strain HAMBI 1141 (symbiovar officinalis). The genome sequences revealed a previously unrecognized nod gene, noeT, in close vicinity of the known symbiosis genes.

Nod factors of rhizobia other than N. galegae have been found to have acetyl moieties substituted on the terminal GlcNAc residues, the function encoded by genes nodL, nodX and nolL. The nodL gene has been shown to introduce one $O$-acetyl moiety at the C-6 position of the nonreducing-terminal GlcNAc residue in $R$. leguminosarum $[28,29]$. The ability of $R$. leguminosarum sv. viciae strain TOM to nodulate $\mathrm{cv}$. Afghanistan pea is dependent on the product of the $\operatorname{nodX}$ gene, which is required for $O$ acetylation of the C- 6 of the reducing-terminal residue of the GlcNAc backbone of NodRlv-V(Ac, $\mathrm{C}_{18: 4}$ ) [30]. However, evidence has also been found that $\operatorname{nodX}$ can be functionally replaced by nodZ, producing a NF that is fucosylated on the reducing-terminal residue [31]. A third type of acetyl transferase involved in modifying Nod factors is NolL, which $\mathrm{O}$-acetylates the $\mathrm{C} 4$ position of the fucose residue located on the reducing-terminal backbone residue in NFs of Mesorhizobium loti (formerly Rhizobium loti) [32], R. etli [33] and S. fredii NGR234 (formerly Rhizobium sp. NGR234) [34].

The noeT gene of $N$. galegae is highly similar to the $h s n T$ gene in R. leguminosarum sv. trifolii ICC105 (accession number EU919402). There is no published evidence for the function of this $h s n T$ gene, which is assigned a putative acetyl transferase function. Since the noeT gene is located in the symbiosis gene region and has a nod-box, the homology with $h s n T$ indicated that this could be the acetyltransferase gene involved in $N$. galegae Nod factor biosynthesis. Recently, $h s n T$ genes homologous to the $R$. leguminosarum sv. trifolii ICC105 hsnT gene have been revealed in other rhizobial strains: $R$. tropici CIAT 899 [22] (protein YP_007336040), R. tropici WUR1 [35] (protein AFJ42562) and R. grahamii CCGE 502 [36] (protein
WP_016558512). No function has, however, yet been described for the $h s n T$ genes in these strains. The NFs of CIAT 899 have been analysed [37-39], but no acetyl substituent has been reported in the same position as in $N$. galegae. The acetyl substituent of $N$. galegae is in a very unusual position, on the GlcNAc residue adjacent to the non-reducing-terminal residue, while Nod factors of CIAT 899 are acetylated on the non-reducing-terminal residue. Given the unusual position of the acetyl substituent, it was for a long time thought to be important for the very strict host specificity of $N$. galegae. To date, the only strains known to produce NFs modified in the same position are M. loti NZP2213 which has a fucose in this position $[9,40]$, and Mesorhizobium sp. strain $\mathrm{N}_{33}$ (Oxytropis arctobia) and Rhizobium sp. BR816 (broad-host range strain isolated from Leucaena leucocephala) which can bear an acetyl substituent in the same position $[9,41,42]$. The fucose residue of NZP2213 does not appear to extend or limit host-range specificity in comparison to other M. loti strains which lack NFs with this modification, and it was thus suggested to provide protection of the NF against degradation or to be an adaptation to a particular as yet unidentified hostspecific receptor [40]. No specific biological function for the acetyl substituent on the nonterminal GlcNAc residue has been reported for strain BR816, nor has any functional gene been assigned in this strain. However, there is high sequence similarity between NoeT of $N$. galegae and a pair of hypothetical proteins in BR816 (WP_018240294 and WP_01824095). When compared to nodL, nodX and nolL genes, the $N$. galegae acetyltransferase gene shows highest similarity to TOM nodX, with $42 \%$ positives ( $27 \%$ identity) over a 318 residues long alignment (out of 639 residues in N. galegae).

Mass spectometric analysis of the NFs of the wild type strain HAMBI 1174 and the noeT deletion mutant HAMBI 3275 revealed LCO structures that differ from those reported by Yang and associates (1999) [11] in backbone length and fatty acyl substitution. In the previous work, strains overexpressing the nod genes were used, which might have caused the structural difference in the fatty acyl chain [43]. In addition, we have here detected a methylated LCO among HAMBI 1174 NFs (Table 2). The methyl group is located on the reducing-terminal position, another rare position for NF substitutions [9]. The genetic 
determinants for this substitution are, however, unknown. Nevertheless, in this study, mass spectrometric analysis clearly showed that the NFs of the mutant strain lack the acetyl substituent on the GlcNAc residue adjacent to the non-reducing-terminal residue, while a majority of the wild-type NFs are acetylated. This is consistent with the assumption that noeT encodes a protein that is responsible for the addition of this acetyl moiety to the LCO. Nod factors of the sv. officinalis strain HAMBI 1207, a derivative strain of HAMBI 1141, have been shown to be identical to those of symbiovar orientalis [11], indicating that this gene probably has the same function in both symbiovars. Plant experiments showed that deletion of this gene does not affect the ability of N. galegae HAMBI 1174 to induce effective nodules on $G$. orientalis, showing that noeT alone is not directly responsible for the host specific nodulation of $N$. galegae. Furthermore, $R$. tropici CIAT 899, containing a homologous protein [22], was not able to form nodules on $G$. orientalis when tested in our laboratory. The inability of the mutant strain to induce nodules on $T$. repens, $P$. sativum cv. Afghanistan, P. vulgaris, $V$. hirsuta or A. sinicus also indicates that the presence of the acetyl moiety is not the reason, or at least not the sole reason, behind the inability of $N$. galegae to nodulate these plant species.

Even though initiation of symbiosis was not affected by the altered NF structure in the mutant, and nodules were formed at an equal rate for both wild type and mutant strains during the first two weeks post inoculation (Figure 7), the final number of nodules was significantly lower for the mutant compared with the wild type at the end of the experiment. It has been suggested that Nod factor substitutions can protect NFs against degradation by plant chitinases $[44,45]$. One possible explanation for the mutant phenotype observed in the plant experiment of this study is that the acetyl moiety on the $N$. galegae NF might provide a protective function against degradation. This concept was also suggested previously [41]. Assuming that the concentration of NF-degrading compounds increases with time, this could explain why nodule formation on plants inoculated with the mutant strain stagnates after 16 days post-inoculation (Figure 7). The same role has been suggested for the fucose residue present in the corresponding position on the M. loti NZP2213 LCO [40]. Nevertheless, the possibility that $n o e T$ is important for host specificity under conditions not tested here must not be excluded.

\section{Are all genes in the symbiosis gene region coupled to functions in symbiosis?}

In addition to the noeT gene, there are some other genes in the symbiosis gene region that deserve attention. The symbiosis gene regions of the sequenced strains share the same complement of genes with one exception, an additional sigma factor gene, rpoN2, found in HAMBI $540^{\mathrm{T}}$. Many genes in block 2 of Figure 5 are regulated by NifA and RpoN [46]. In $R$. etli, there is evidence that separate $r p o N$ genes are involved in regulation under freeliving and symbiotic conditions [47]. The two rpoN genes in HAMBI $540^{\mathrm{T}}$ have $87 \%$ amino acid identity, but only $41 \%$ over the first 41 amino acids. In Rhodobacter sphaeroides, this region of rpoN (region I) has been shown to be important for promoter recognition and for interaction with the activator protein [48]. The rpoN2 gene of HAMBI $540^{\mathrm{T}}$ is preceded by a predicted hypothetical gene (RG540_PA10540, Figure 5) containing a TRX family domain. However, this gene does not have any significant similarity to the NifA-regulated peroxiredoxin genes found upstream of $r p o N$ in the symbiosis regions of $R$. etli $[46,47]$. Thus, studies need to be conducted to investigate if rpoN2 in HAMBI $540^{\mathrm{T}}$ is involved in regulation of symbiosis genes, and to determine if this gene contributes to the difference in nitrogen fixation observed between strains of symbiovars orientalis and officinalis.

$N$. galegae also has two versions of the $\mathrm{C}_{4}$-dicarboxylate carrier protein-coding gene $\operatorname{dct} A$ : one on the chromosome and one in the symbiosis gene region downstream of nifQ (Figure 5). Results of GenBank searches indicate that the genomic context of nifQ followed by $\operatorname{dct} A$ is common among strains of $S$. fredii. There are, however, conflicting data as to whether the second copy of $d c t A$ is essential or not for symbiotic nitrogen fixation $[49,50]$. A possible explanation for the extra copy of $d c t A$ in the symbiosis gene region might be that it leads to a more efficient energy intake at times when the symbiosis genes are expressed. The NifQ protein in $N$. galegae has, on the other hand, diverged remarkably from NifQ proteins in other rhizobia, even lacking the molybdenum-binding motif. Analysis of the ratio of nonsynonymous/synonymous substitution rates showed that nifQ has a relatively higher rate of nonsynonymous substitutions than any other gene in the symbiosis gene region (Figure 6). Analyses of the evolution of $N$. galegae nifQ in relation to other rhizobial species indicated that the evolution of this gene is not due to positive selection but a higher level of nonsynonymous mutations. This and the fact that the molybdenumbinding motif is missing from nifQ indicates that this gene is possibly nonessential for $N$. galegae, and is most probably a nonfunctional pseudogene. At this point, there is no evidence that nifQ is functional in $N$. galegae.

The nodO gene is located immediately downstream of dctA. NodO is a calcium-binding protein which is exported to the growth medium without cleavage of the N-terminal region [51]. Based on the location of the T1SS genes, directly downstream of nodO (Figure 5), together with their similarity to the prs $D E$ genes previously found to be responsible for NodO secretion in $R$. 
leguminosarum [52], it seems probable that these two genes are responsible for transporting the NodO protein out of the cell. This might, however, be a N. galegae-specific system, because BLAST alignments showed that the fragment used by Tas et al. to design species-specific PCR primers for $N$. galegae [53] originates from the T1SS gene RG540_PA10320. The arrangement of T1SS genes directly downstream of nodO is different from the arrangement in many other nodO-containing rhizobia, where the main genes responsible for NodO secretion mainly seem to be located distantly from the nodO gene itself $[51,52]$. Many T1SSs require a third protein in the form of an outer membrane protein to function, but in $N$. galegae no such ORF is found downstream of the two T1SS genes. Similarly, there was no OMP identified in the prsDE system of $R$. leguminosarum [52], although the authors speculated that a protein that is not linked to the prs $D E$ genes is contributing to NodO secretion. The nodO gene has been shown to compensate for mutations in nodFE of $R$. leguminosarum sv. viciae in nodulation of vetch and of pea, although restoration of nodulation of pea requires nod $L$ in addition to nodO when nodFE is not present [54]. In addition, nodO from Rhizobium sp. BR816 suppressed the nodulation defect of $S$. fredii NGR234 and $R$. tropici CIAT 899 nodU mutants on the host plant $L$. leucocephala [55]. NodO has also been reported to have an effect the host range of certain rhizobia [55,56]. Sutton et al. [57] proposed that the cation fluxes across the plasma membrane induced by NodO may amplify the response induced by NFs. Perhaps nodO can also compensate for the noeT mutation in N. galegae?

\section{Secretion systems may play a role in symbiosis}

The presence of a third replicon in HAMBI 1141 was determined previously [1], but now we can confirm that this additional plasmid is an important part of the genome. The fact that genes required for symbiosis are held on the plasmid, together with genes for conjugative transfer is interesting from an evolutionary perspective. Experiments performed in this work showed that $N$. galegae sv. officinalis strain HAMBI 1207 was able to transfer its symbiosis plasmid to the nod mutant sv. orientalis strain HAMBI 1587. However, transconjugants were observed only among cells from a selective plate where exconjugants were plated without dilution. This indicates that the transfer frequency might be very low, a conclusion that is also supported by the fact that no true transconjugants were found when HAMBI 1141 was mated with A. fabrum strain C58C1 and the nod mutant strains $S$. meliloti HAMBI 1213 and $R$. leguminosarum sv. viciae HAMBI 1594. These strains have previously been shown to induce root nodules on the hosts Medicago sativa (A. fabrum and S. meliloti) and Vicia villosa ( $R$. leguminosarum) when complemented with a cosmid clone containing common nod genes of $N$. galegae
HAMBI 1174 [58]. It is also not possible to exclude a scenario where donor cells were still present on the selective plate, so that conjugation may have taken place only at the inoculation stage, in the presence of the plant. Regulation of $t r a R$ transcription activator gene expression, and thereby regulation of tra gene expression, by plant metabolites has been suggested for $S$. fredii strain NGR234, which has T4SS genes homologous to those found on pHAMBI1141b on its plasmid pSfrNGR234a [59]. Nevertheless, when conjugation was attempted between HAMBI3490 and HAMBI 1587 it resulted in the absence of transconjugants irrespective of whether the cells were diluted or not prior to selection for the recipient. This indicates that the lack of transfer was not due to low transfer frequency, but rather the lack of the T4SS genes on the chromid. The inability of HAMBI 1141 to transfer its symbiosis plasmid to the corresponding plasmid-cured strain indicates that there is an additional factor restricting plasmid transfer between $N$. galegae strains that differ only in the presence of the symbiosis plasmid. However, the results obtained in this study indicate that despite the presence of all necessary genes for a self-transmissible plasmid, the symbiosis plasmid in HAMBI 1141 is not self-transmissible. It remains to be shown whether some of these genes are in fact nonfunctional. However, it can be noted that type IV secretion in $N$. galegae is most likely not involved in directing symbiosis, because no nod boxes have been found upstream from the T4SS operons.

Type VI secretion, on the other hand, has been reported to be important for symbiosis-related functions in nitrogen fixation: R. leguminosarum strain RBL5523, which normally induces ineffective nodules on pea, gained the ability to induce effective nodules when the imp operon was mutated [60]. The T6SS found in HAMBI $540^{\mathrm{T}}$ might also contribute to its host specificity, considering that this feature is not found in the sv. officinalis strain HAMBI 1141. Future work will shed light on the role of the T6SS in strain HAMBI $540^{\mathrm{T}}$.

\section{Conclusions}

This study demonstrates that despite the distinct symbiotic properties, there is a high degree of genomic similarity between the two symbiovars of $N$. galegae, represented by strains HAMBI $540^{\mathrm{T}}$ and HAMBI 1141 . The availability of the genome sequences will be invaluable for future research on $N$. galegae. The results of this work also showed that, based on the number of shared orthologous genes and genomic alignments, $N$. galegae is more closely related to $R$. leguminoarum sv. viciae 3841 than to $A$. fabrum C58, S. meliloti 1021, R. tropici CIAT 899 or S. medicae WSM419. In addition, we report for the first time the gene responsible for acetylation of the GlcNAc residue adjacent to the non-reducing-terminal residue on the $N$. galegae Nod factors. We have named this gene noeT, a 
name reflecting the function involved in shaping the Nod factor albeit not directly determining host specificity as the gene name $h s n T$ implies. We have demonstrated that the noeT gene alone is not essential for nodulation of Galega plants, but we speculate that it might have a protective effect on the Nod factor of N. galegae. We have also shown that the symbiosis plasmid of HAMBI 1141 is conjugative, although it does not seem to be selftransmissible.

\section{Methods}

\section{Bacterial strains and growth conditions}

Strains and plasmids used in this study are described in (Additional file 2: Table S1). N. galegae strains HAMBI $540^{\mathrm{T}}$, HAMBI 1141 and HAMBI 1174 and $R$. tropici strain CIAT 899 (HAMBI 1163) were obtained from the HAMBI culture collection (University of Helsinki, Faculty of Agriculture and forestry, Division of Microbiology and Biotechnology). The rhizobial strains were grown on TY or YEM agar plates and in TY broth. Culture media of HAMBI 1174 and its noeT mutant were supplied with spectinomycin $(500 \mu \mathrm{g} / \mathrm{mL})$ and neomycin $(25 \mu \mathrm{g} / \mathrm{mL})$ respectively. E. coli strains used for mutant construction were grown in LB media. Media were supplied with appropriate antibiotics: streptomycin $30 \mu \mathrm{g} /$ $\mathrm{mL}$, spectinomycin $50 \mu \mathrm{g} / \mathrm{mL}$, gentamicin $25 \mu \mathrm{g} / \mathrm{mL}$, kanamycin $50 \mu \mathrm{g} / \mathrm{mL}$.

\section{DNA isolation}

Total DNA of strains HAMBI $540^{\mathrm{T}}$ and HAMBI 1141 was isolated using a CTAB (hexadecyltrimethylammonium bromide) procedure modified from Wilson (1994) [61] (see Additional file 2 for detailed description). Plasmid DNA was isolated using the GeneJET Plasmid Miniprep Kit (Thermo Scientific). DNA for PCR verification of clones was isolated using the PrepMan Ultra Sample Preparation Reagent (Applied Biosystems), applying the protocol for preparation of samples for bacterial and fungal testing from culture broths.

\section{Genome sequencing, assembly and annotation}

A library was constructed from HAMBI $540^{\mathrm{T}}$ and HAMBI 1141 DNA and sequenced on a Genome Sequencer FLX Titanium (Roche). The obtained sequences were assembled using Newbler (Roche). One mate-pair library (1.5 $3.5 \mathrm{~kb}$ ) for each strain was constructed using the SOLiD mate-pair library kit and sequenced on a SOLiD4 Sequencer (Life Technologies). The obtained sequences were used for scaffolding and correction of homopolymer errors in the 454 contigs. PCR and Sanger sequencing was used for closing of the gaps in the scaffolds. The final closure was done using long reads obtained from two SMRT cells for both genomes run on a PacBio RS (Pacific Biosciences) (see Additional file 2 for detailed description).
Gene prediction was done with Prodigal ver. 2.50 [62] as part of the PANNZER annotation pipeline (Koskinen et al. unpublished). The tRNA genes were annotated using tRNAscan-SE 1.3.1 [63] and rRNA genes identified with RNAmmer 1.2 [64]. The gene predictions were manually checked using the Artemis software [65]. To ascertain the validity of the third chromid criterion (core genes found on the chromosome in other species) in N. galegae, the blastp service was used to determine homology of the protein sequences of the genes on the chromids (as predicted by Prodigal) to the set of 280 core genes of 69 taxa initially used to define chromids [12], with a threshold of minimum $70 \%$ identity. A complete list of the genes in the genomes is provided in an additional file (see Additional file 3). The genome sequences were submitted to the European Nucleotide Archive: [EMBL:HG938355-HG938357] and [EMBL:HG938353HG938354]. The sequences can be accessed through the links http://www.ebi.ac.uk/ena/data/view/HG938353HG938354 (HAMBI 540 ${ }^{\mathrm{T}}$ ) and http://www.ebi.ac.uk/ena/ data/view/HG938355-HG938357 (HAMBI 1141).

\section{Bioinformatics analyses}

The two sequenced genomes were aligned using the genome alignment software progressiveMauve [66], using default options. Genes were assigned to COG categories by an RPS-BLAST search (as part of the NCBI toolbox) against the COG collection [67] in the conserved domain database [68]. The OrthoMCL software [69] was used to find ortholog groups between the two strains of $N$. galegae and related rhizobial strains. The software was run with default settings. Custom Perl, Python and Biopython [70] scripts were used to modify output from these analyses and to create data files for Circos [71], which was used to make circular data representations of the genomes. A structural genomics analysis comparing the two $N$. galegae genomes with the complete genomes of strains $R$. leguminosarum sv. viciae 3841, $R$. tropici CIAT 899, S. medicae WSM419 and S. meliloti 1021 was generated using the megablast algorithm [72], retaining only hits with an alignment length of at least $1000 \mathrm{bp}$. These results were visualised with Artemis Comparison Tool (ACT) [73]. The reference genomes used for alignments of pHAMBI1141b and related rhizobial strains are listed in Additional file 2: Table S2). CodonW [74] was used for analysis of total codon usage. For this analysis chromosomal genes only were used. Hypothetical genes with no sequence identity with other proteins were removed from the data set, as well as transposon- and phage-related genes and genes shorter than 50 aa. A description of the analysis of evolutionary history of the RepABC systems and the analyses of substitution rates and positive selection in the nifQ gene is provided in Additional file 2. 


\section{noeT mutant construction and Nod factor analysis} A noeT gene replacement mutant (strain HAMBI 3275) was constructed in HAMBI 1174 to study the function of this gene in symbiosis. Nod factors of this mutant and its wild-type parental strain were extracted and analysed by mass spectrometry. The effect of the mutation on nodule formation and nitrogen fixation was assessed through plant inoculation assays on the original host plant, G. orientalis. The mutant strain was also tested on host plants of other rhizobial strains to check whether the mutation had an effect on host range. The methods for mutant construction, Nod factor extraction, mass spectrometric analysis and plant assays are described in detail in Additional file 2.

\section{HAMBI 1141 symbiosis plasmid conjugation tests}

In order to study whether the symbiosis plasmid of strain HAMBI 1141 is conjugative, conjugation tests were performed between HAMBI 1141 or its streptomycinresistant derivative strain HAMBI 1207 and nodulation defective strains of both symbiovars of $N$. galegae, $S$. meliloti, $R$. leguminosarum and A. fabrum. A plasmid-cured derivative of HAMBI 1207 as well as a HAMBI 1141 deletion mutant lacking the T4SS gene region on the chromid, were constructed to study the impact of the chromid-borne T4SS genes on conjugation of the symbiosis plasmid. Biparental matings, plant tests and transconjugant confirmation was performed as described in Additional file 2.

\section{Availability of supporting data}

The data sets supporting the results of this article are included within the article and its additional files. The complete genome sequences of $N$. galegae strains HAMBI $540^{\mathrm{T}}$ and HAMBI 1141 are publicly available in the European Nucleotide Archive with accession numbers HG938353-HG938354 (HAMBI 540 ${ }^{\mathrm{T}}$ ) and HG938355HG938357 (HAMBI 1141) (http://www.ebi.ac.uk/ena/data/ view/HG938353-HG938354, http://www.ebi.ac.uk/ena/data/ view/HG938355-HG938357). Accession numbers of reference sequences used are included in Additional file 2.

\section{Additional files}

Additional file 1: Figure S1. ML phylogeny of concatenated RepABC protein sequences from N. galegae strains HAMBI 540 ${ }^{\top}$ and $\mathrm{HAMBI} 1141$, and 12 strains representing Rhizobium, Sinorhizobium, Mesorhizobium and Agrobacterium. Figure S2: A figure illustrating the location of singletons of N. galegae strains $\mathrm{HAMBI} 540^{\top}$ and $\mathrm{HAMBI} 1141$ identified in the OrthoMCL analysis with 5 genomes. The inner ring shows the COG categories of these singletons. Figure S3: A figure illustrating the location of orthologous genes of $N$. galegae strains $\mathrm{HAMBI} 540^{\top}$ and $\mathrm{HAMBI} 1141$. Orthologs between any gene in HAMBI 1141 and a gene located on the chromosome of $\mathrm{HAMBI} 540^{\top}$ are shown with a blue link, while orthologs located on any replicon in HAMBI 1141 and on the chromid of HAMBI $540^{\top}$ are shown in green. Figure S4: A Maximum likelihood tree of rhizobial nifQ sequences. This tree was used for PAML analyses, without branch lengths. Figure S5: RP-HPLC fractionation of $N$. galegae $\mathrm{HAMBI}$ 1174 and noeT mutant strain LCO-containing SPE fractions a) HAMBI 1174 (45\% SPE fraction) b) HAMBI 1174 (60\% SPE fraction), c) noeT mutant (45\% SPE fraction) d) noeT mutant (60\% SPE fraction). Regions 2 and 3 correspond to known elution positions for LCOs. The region marked 1 was shown to contain a strongly UV-absorbing polymeric contaminant no LCOs were detected in this region. Figure S6: CID product ion spectrum of the LCO from wild type strain N. galegae HAMBI 1174 giving an $[\mathrm{M}+\mathrm{H}]^{+}$ion at $\mathrm{m} / \mathrm{z} 1162$, eluting with retention time 46 minutes. Figure S7: CID product ion spectrum of N. galegae HAMBI 1174 noeT mutant strain NF at $\mathrm{m} / \mathrm{z} 1118\left([\mathrm{M}+\mathrm{Na}]^{+}\right)$at retention time 45 minutes.

Additional file 2: This text file contains a detailed description of the materials and methods used in this study. Table S1 Strains and plasmids used in this study. Table S2 Accession numbers of reference genomes used. Table S3 Accession numbers of RepABC sequences used. Table S4 Primers used in this study.

Additional file 3: Lists of all genes predicted in the genomes of $N$. galegae strains HAMBI 540 and HAMBI 1141.

\section{Abbreviations}

NF: Nod factor; LCO: Lipochitin oligosaccharide; GlcNAc: $\beta$-1,4-linked $\mathrm{N}$-acetylglucosamine; COG: Clusters of Orthologous Groups; EPS: Exopolysaccharide; LPS: Lipopolysaccharide; Flp/Tad: Fimbrial low-molecular-weight protein/tight adherence protein; T1SS: Type I secretion system; IS: Insertion sequence; ABC: ATP binding cassette; LRT: Likelihood ratio test; ML: Maximum likelihood; RP-HPLC: Reversed phase highperformance liquid chromatography; SPE: Solid phase extraction; ESIMS: Electrospray ionization mass spectrometry; MALDI-MS: Matrix-assisted laser desorption/ionization mass spectrometry; CID: Collision-induced dissociation; OMP: Outer membrane protein.

\section{Competing interests}

The authors declare that they have no competing interests.

\section{Authors' contributions}

JÖ participated in the design of the study, carried out the molecular genetic studies and the plant assays, performed bioinformatics analyses of the genome data and wrote the main part of the manuscript. JM carried out the mass spectrometry work and, together with JTO, interpreted those data and wrote the mass spectrometry results for the manuscript. PKL, EA and LP carried out genome sequencing and assembly. LP was responsible for design and coordination of the genome sequencing and wrote the description of the genome sequencing procedure for the manuscript. $\mathrm{ZZ}$ carried out most of the experimental work on conjugational plasmid transfer and assisted in writing the results of this work. JTS participated in design of the molecular genetic studies and in editing of the manuscript. JPWY participated in the design of the genomic study and in editing of the manuscript. JTO designed and coordinated the mass spectrometric work. KL conceived the study, participated in its design and coordination and helped to draft the manuscript. All authors read and approved the final manuscript.

\section{Acknowledgements}

We would like to thank Peter Harrison for his advice in confirming the chromid criteria, Patrik Koskinen for running the functional annotation, Pe Johansson for excellent guidance in bioinformatics analyses and Professor Clive Ronson for discussions on the hsnT gene and the establishment of collaborations that underpinned the project. Technical staff at the DNA sequencing and Genomics laboratory, Institute of Biotechnology, University of Helsinki, are acknowledged for assistance in preparation of genomic material for sequencing. Masters student Sharmin Ahamed is acknowledged for carrying out experiments related to the conjugational transfer of the symbiotic plasmid in strain HAMBI 1141. We thank Mike Ambrose at the John Innes Centre for providing seeds of P. sativum CV. Afghanistan. Special thanks goes to Paul Buckley and his friends, who collected G. officinalis seeds for us in New Zealand. We also thank the Michael Hynes lab for providing strains for the plamid curing work, and the AG Schüler lab for providing plasmids for the Cre-lox work. Leena Suominen is acknowledged for critical review of the manuscript. We used the resources of the CSC (Finnish IT Center for Science, Helsinki, Finland) Hippu and Taito clusters for sequence analysis. The work was done as part of the SYMBEF project supported by the 
Academy of Finland (project 132544). JÖ acknowledges support from the Swedish Cultural Foundation in Finland (grant 13/7440-1304). The York Centre of Excellence in Mass Spectrometry was created thanks to a major capital investment through Science City York, supported by Yorkshire Forward with funds from the Northern Way Initiative.

\section{Author details}

'Department of Food and Environmental Sciences, University of Helsinki, Viikinkaari 9, 00790 Helsinki, Finland. ${ }^{2}$ Institute of Biotechnology, University of Helsinki, Viikinkaari 9, 00790 Helsinki, Finland. ${ }^{3}$ Department of Environmental Sciences, University of Helsinki, Viikinkaari 2a, 00790 Helsinki, Finland. ${ }^{4}$ Department of Microbiology and Immunology, University of Otago, Dunedin 9054, New Zealand. ${ }^{5}$ Department of Biology, University of York, Heslington, York YO10 5DD, UK. ${ }^{6}$ Department of Chemistry, University of York, Heslington, York YO10 5DD, UK. 'Centre of Excellence in Mass Spectrometry, University of York, Heslington, York YO10 5DD, UK.

Received: 21 March 2014 Accepted: 12 June 2014

Published: 19 June 2014

\section{References}

1. Lindström K: Rhizobium galegae, a new species of legume root nodule bacteria. Int J Syst Bacteriol 1989, 39:365-367.

2. Mousavi SA, Österman J, Wahlberg N, Nesme X, Lavire C, Vial L, Paulin L, de Lajudie P, Lindström K: Phylogeny of the Rhizobium-Allorhizobium Agrobacterium clade supports the delineation of Neorhizobium gen. nov. Syst Appl Microbiol 2014, 37:208-215.

3. Martens M, Dawyndt P, Coopman R, Gillis M, De Vos P, Willems A: Advantages of multilocus sequence analysis for taxonomic studies: a case study using 10 housekeeping genes in the genus Ensifer (including former Sinorhizobium). Int I Syst Evol Micr 2008, 58:200-214.

4. Terefework Z, Nick G, Suomalainen S, Paulin L, Lindström K: Phylogeny of Rhizobium galegae with respect to other rhizobia and agrobacteria. Int J Syst Bacteriol 1998, 48:349-356.

5. Radeva G, Jurgens G, Niemi M, Nick G, Suominen L, Lindström K: Description of two biovars in the Rhizobium Galegae species: biovar orientalis and biovar officinalis. Syst Appl Microbiol 2001, 24:192-205.

6. Guasch-Vidal B, Estévez J, Dardanelli MS, Soria-Díaz ME, Fernández de Córdoba F, Balog CIA, Manyani H, Gil-Serrano A, Thomas-Oates J, Hensbergen PJ, Deelder AM, Megías M, van Brussel AAN: High $\mathrm{NaCl}$ concentrations induce the nod genes of Rhizobium tropici CIAT899 in the absence of flavonoid inducers. Mol Plant-Microbe Interact 2013, 26:451-460.

7. Mergaert $\mathrm{P}, \mathrm{Van}$ Montagu M, Holsters M: Molecular mechanisms of Nod factor diversity. Mol Microbiol 1997, 25:811-817.

8. Dénarié J, Debellé F, Promé JC: Rhizobium lipo-chitooligosaccharide nodulation factors: signaling molecules mediating recognition and morphogenesis. Annu Rev Biochem 1996, 65:503-535.

9. D'Haeze W, Holsters M: Nod factor structures, responses, and perception during initiation of nodule development. Glycobiology 2002, 12:79R-105R.

10. Perret $X$, Staehelin C, Broughton WJ: Molecular basis of symbiotic promiscuity. Microbiol Mol Biol R 2000, 64:180-201.

11. Yang G, Debellé F, Savagnac A, Ferro M, Schiltz O, Maillet F, Promé D, Treilhou M, Vialas C, Lindström K, Dénarié J, Promé J: Structure of the Mesorhizobium huakuii and Rhizobium galegae Nod factors: a cluster of phylogenetically related legumes are nodulated by rhizobia producing Nod factors with $a$, $\beta$-unsaturated N-acyl substitutions. Mol Microbiol 1999, 34:227-237.

12. Harrison PW, Lower RPJ, Kim NKD, Young JPW: Introducing the bacterial 'chromid': not a chromosome, not a plasmid. Trends Microbiol 2010, 18:141-148.

13. Glucksmann MA, Reuber TL, Walker GC: Genes needed for the modification, polymerization, export, and processing of succinoglycan by Rhizobium meliloti: a model for succinoglycan biosynthesis. J Bacteriol 1993, 175:7045-7055

14. Sharypova LA, Niehaus K, Scheidle H, Holst O, Becker A: Sinorhizobium meliloti acpXL mutant lacks the C28 hydroxylated fatty acid moiety of lipid $A$ and does not express a slow migrating form of lipopolysaccharide. J Biol Chem 2003, 278:12946-12954.

15. Räsänen LA, Russa R, Urbanik T, Choma A, Mayer $H$, Lindström K: Characterization of two lipopolysaccharide types isolated from Rhizobium galegae. Acta Biochim Pol 1997, 44:819-825.

16. Nykyri J, Mattinen L, Niemi O, Adhikari S, Kõiv V, Somervuo P, Fang X, Auvinen P, Mäe A, Palva ET, Pirhonen M: Role and Regulation of the Flp/
Tad Pilus in the Virulence of Pectobacterium atrosepticum SCRI1043 and Pectobacterium wasabiae SCC3193. PLoS One 2013, 8:e73718.

17. Bedmar EJ, Robles EF, Delgado MJ: The complete denitrification pathway of the symbiotic, nitrogen-fixing bacterium Bradyrhizobium japonicum. Biochem Soc Trans 2005, 33:145-148.

18. Monza J, Irisarri P, Díaz P, Delgado MJ, Mesa S, Bedmar E: Denitrification ability of rhizobial strains isolated from Lotus sp. Antonie Van Leeuwenhoek 2006, 89:479-484.

19. Sánchez C, Tortosa G, Granados A, Delgado A, Bedmar EJ, Delgado MJ: Involvement of Bradyrhizobium japonicum denitrification in symbiotic nitrogen fixation by soybean plants subjected to flooding. Soil Biol Biochem 2011, 43:212-217.

20. Ding $H$, Yip CB, Hynes MF: Genetic characterization of a novel rhizobial plasmid conjugation system in Rhizobium leguminosarum bv. viciae strain VF39SM. J Bacteriol 2013, 195:328-339.

21. Lin J, Ma L, Lai E: Systematic dissection of the Agrobacterium type VI secretion system reveals machinery and secreted components for subcomplex formation. PLoS One 2013, 8:e67647.

22. Ormeño-Orrillo E, Menna P, Almeida LGP, Ollero FJ, Nicolás MF, Rodrigues EP, Nakatani AS, Batista JSS, Chueire LMO, Souza RC, Vasconcelos ATR, Megías M, Hungria M, Martínez-Romero E: Genomic basis of broad host range and environmental adaptability of Rhizobium tropici CIAT 899 and Rhizobium sp. PRF 81 which are used in inoculants for common bean (Phaseolus vulgaris L.). BMC Genomics 2012, 13:735.

23. Oresnik IJ, Twelker S, Hynes MF: Cloning and characterization of a Rhizobium leguminosarum gene encoding a bacteriocin with similarities to RTX toxins. Appl Environ Microbiol 1999, 65:2833-2840.

24. Hernandez JA, Curatti L, Aznar CP, Perova Z, Britt RD, Rubio LM: Metal trafficking for nitrogen fixation: NifQ donates molybdenum to NifEN/ $\mathrm{NifH}$ for the biosynthesis of the nitrogenase FeMo-cofactor. Proc Natl Acad Sci USA 2008, 105:11679-11684.

25. Suominen L, Roos C, Lortet G, Paulin L, Lindström K: Identification and structure of the Rhizobium galegae common nodulation genes: evidence for horizontal gene transfer. Mol Biol Evol 2001, 18:907-916.

26. Suominen L, Paulin L, Saano A, Saren A, Tas E, Lindström K: Identification of nodulation promoter (nod-box) regions of Rhizobium galegae. FEMS Microbiol Lett 1999, 177:217-223.

27. Songsrirote K: Glycoconjugate mass spectrometry from pathology to symbiosis. In PhD thesis. University of York, Department of Chemistry: 2010.

28. Spaink HP, Sheeley DM, van Brussel AAN, Glushka J, York WS, Tak T, Geiger O, Kennedy EP, Reinhold VN, Lugtenberg BJJ: A novel highly unsaturated fatty acid moiety of lipo-oligosaccharide signals determines host specificity of Rhizobium. Nature 1991, 354:125-130.

29. Bloemberg GV, Thomas-Oates JE, Lugtenberg BJJ, Spaink HP: Nodulation protein NodL of Rhizobium leguminosarum $\mathrm{O}$-acetylates lipo-oligosaccharides, chitin fragments and N-acetylglucosamine in vitro. Mol Microbiol 1994, 11:793-804.

30. Firmin JL, Wilson KE, Carlson RW, Davies AE, Downie JA: Resistance to nodulation of $\mathrm{cv}$. Afghanistan peas is overcome by nodX, which mediates an $\mathrm{O}$-acetylation of the Rhizobium leguminosarum lipo-oligosaccharide nodulation factor. Mol Microbiol 1993, 10:351-360.

31. Ovtsyna AO, Geurts R, Bisseling T, Lugtenberg BJJ, Tikhonovich IA, Spaink HP: Restriction of host range by the sym2 allele of Afghan pea is nonspecific for the type of modification at the reducing terminus of nodulation signals. Mol Plant-Microbe Interact 1998, 11:418-422.

32. Scott DB, Yound CA, Collins-Emerson JM, Terzaghi EA, Rockman ES, Lewis PE, Pankhurst CE: Novel and complex chromosomal arrangement of Rhizobium loti nodulation genes. Mol Plant-Microbe Interact 1996, 9:187-197.

33. Corvera A, Promé D, Promé J, Martínez-Romero E, Romero D: The noll gene from Rhizobium etli determines nodulation efficiency by mediating the acetylation of the fucosyl residue in the nodulation factor. Mol PlantMicrobe Interact 1999, 12:236-246.

34. Berck S, Perret X, Quesada-Vincens D, Promé J, Broughton WJ, Jabbouri S: NolL of Rhizobium sp. strain NGR234 is required for O-acetyltransferase activity. J Bacteriol 1999, 181:957-964.

35. Op den Camp RHM, Polone E, Fedorova E, Roelofsen W, Squartini A, Op den Camp HJM, Bisseling T, Geurts R: Nonlegume Parasponia andersonii deploys a broad rhizobium host range strategy resulting in largely variable symbiotic effectiveness. Mol Plant-Microbe Interact 2012, 25:954-963.

36. Althabegoiti MJ, Lozano L, Torres-Tejerizo G, Ormeño-Orrillo E, Rogel MA, González V, Martínez-Romero E: Genome sequence of Rhizobium grahamii 
CCGE502, a broad-host-range symbiont with low nodulation competitiveness in Phaseolus vulgaris. J Bacteriol 2012, 194:6651-6652.

37. Morón B, Soria-Díaz ME, Ault J, Verroios G, Noreen S, Rodríguez-Navarro DN, Gil-Serrano A, Thomas-Oates J, Megías M, Sousa C: Low pH changes the profile of nodulation factors produced by Rhizobium tropici CIAT899. Chem Biol 2005, 12:1029-1040.

38. Estévez J, Soria-Díaz ME, de Córdoba FF, Morón B, Manyani H, Gil A, Thomas-Oates J, Van Brussel AA, Dardanelli MS, Sousa C, Megías M: Different and new Nod factors produced by Rhizobium tropici CIAT899 following $\mathrm{Na}+$ stress. FEMS Microbiol Lett 2009, 293:220-231.

39. Folch-Mallol JL, Marroquf S, Sousa C, Manyani H, López-Lara IM, van der Drift KMGM, Haverkamp J, Quinto C, Gil-Serrano A, Thomas-Oates J, Spaink HP, Megías M: Characterization of Rhizobium tropici CIAT899 nodulation factors: the role of nodH and nodPQ genes in their sulfation. Mol Plant-Microbe Interact 1996, 9:151-163.

40. Olsthoorn MMA, López-Lara IM, Petersen BO, Bock K, Haverkamp J, Spaink HP Thomas-Oates J: Novel branched Nod factor structure results from $a-(1 \rightarrow 3)$ fucosyl transferase activity: the major lipo-chitin oligosaccharides from Mesorhizobium loti strain NZP2213 bear an a-( $1 \rightarrow 3)$ fucosyl substituent on a nonterminal backbone residue. Biochemistry 1998, 37:9024-9032

41. Snoeck C, Luyten E, Poinsot V, Savagnac A, Vanderleyden J, Promé J: Rhizobium sp. BR816 produces a complex mixture of known and novel lipochitooligosaccharide molecules. Mol Plant-Microbe Interact 2001, 14:678-684

42. Poinsot V, Bélanger E, Laberge S, Yang G, Antoun H, Cloutier J, Treilhou M, Dénarié J, Promé J, Debellé F: Unusual methyl-branched a, $\beta$-unsaturated acyl chain substitutions in the Nod factors of an arctic rhizobium, Mesorhizobium sp. Strain N33 (Oxytropis arctobia). J Bacterio/ 2001, 183:3721-3728.

43. Schlaman HRM, Olsthoorn MMA, Harteveld M, Dörner L, Djordjevic MA Thomas-Oates J, Spaink HP: The production of species-specific highly unsaturated fatty acyl-containing LCOs from Rhizobium leguminosarum bv. trifolii is stringently regulated by nodD and involves the nodRL genes. Mol Plant-Microbe Interact 2006, 19:215-226.

44. Staehelin C, Schultze M, Kondorosi É, Mellor RB, Boiler T, Kondorosi A: Structural modifications in Rhizobium meliloti Nod factors influence their stability against hydrolysis by root chitinases. Plant J 1994, 5:319-330.

45. Schultze M, Staehelin C, Brunner F, Genetet I, Legrand M, Fritig B, Kondorosi É, Kondorosi Á: Plant chitinase/lysozyme isoforms show distinct substrate specificity and cleavage site preference towards lipochitooligosaccharide Nod signals. Plant J 1998, 16:571-580.

46. Salazar E, Díaz-Mejía JJ, Moreno-Hagelsieb G, Martínez-Batallar G, Mora Y, Mora J, Encarnación S: Characterization of the NifA-RpoN regulon in Rhizobium etli in free life and in symbiosis with Phaseolus vulgaris. Appl Environ Microbiol 2010, 76:4510-4520.

47. Michiels J, Moris M, Dombrecht B, Verreth C, Vanderleyden J: Differential regulation of Rhizobium etli rpoN2 gene expression during symbiosis and free-living growth. J Bacteriol 1998, 180:3620-3628.

48. Poggio S, Osorio A, Dreyfus G, Camarena L: Transcriptional specificity of RpoN1 and RpoN2 involves differential recognition of the promoter sequences and specific interaction with the cognate activator proteins. J Biol Chem 2006, 281:27205-27215.

49. van Slooten JC, Bhuvanasvari TV, Bardin S, Stanley J: Two $\mathbf{C}_{4}$-dicarboxylate transport systems in Rhizobium sp. NGR234: rhizobial dicarboxylate transport is essential for nitrogen fixation in tropical legume symbioses. Mol Plant-Microbe Interact 1992, 5:179-186

50. Fumeaux C, Bakkou N, Kopcińska J, Golinowski W, Westenberg DJ, Müller P, Perret X: Functional analysis of the nifQdctA1y4vGHIJ operon of Sinorhizobium fredii strain NGR234 using a transposon with a NifA-dependent read-out promoter. Microbiology 2011, 157:2745-2758.

51. Economou A, Hamilton WD, Johnston AW, Downie JA: The Rhizobium nodulation gene nodO encodes a $\mathrm{Ca}^{2+}$-binding protein that is exported without $\mathrm{N}$-terminal cleavage and is homologous to haemolysin and related proteins. EMBO J 1990, 9:349-354.

52. Finnie C, Hartley NM, Findlay KC, Downie JA: The Rhizobium leguminosarum prsDE genes are required for secretion of several proteins, some of which influence nodulation, symbiotic nitrogen fixation and exopolysaccharide modification. Mol Microbiol 1997, 25:135-146.

53. Tas É, Leinonen P, Saano A, Räsänen LA, Kaijalainen S, Piippola S, Hakola S, Lindström K: Assessment of competitiveness of rhizobia infecting Galega orientalis on the basis of plant yield, nodulation, and strain identification by antibiotic resistance and PCR. Appl Environ Microbiol 1996, 62:529-535.

54. Downie JA, Surin BP: Either of two nod gene loci can complement the nodulation defect of a nod deletion mutant of Rhizobium leguminosarum bv viciae. Mol Gen Genet 1990, 222:81-86.

55. Vlassak KM, Luyten E, Verreth C, van Rhijn P, Bisseling T, Vanderleyden J: The Rhizobium sp. BR816 nodO gene can function as a determinant for nodulation of Leucaena leucocephala, Phaseolus vulgaris, and Trifolium repens by a diversity of Rhizobium spp. Mol Plant-Microbe Interact 1998, 11:383-392

56. Economou A, Davies AE, Johnston AWB, Downie JA: The Rhizobium leguminosarum biovar viciae nodO gene can enable a nodE mutant of Rhizobium leguminosarum biovar trifolii to nodulate vetch. Microbiology 1994, 140:2341-2347

57. Sutton JM, Lea EJ, Downie JA: The nodulation-signaling protein NodO from Rhizobium leguminosarum biovar viciae forms ion channels in membranes. Proc Natl Acad Sci USA 1994, 91:9990-9994.

58. Räsänen LA, Heikkilä-Kallio U, Suominen L, Lipsanen P, Lindström K: Expression of Rhizobium galegae common nod clones in various backgrounds. Mol Plant-Microbe Interact 1991, 4:535-544.

59. He X, Chang W, Pierce DL, Seib LO, Wagner J, Fuqua C: Quorum sensing in Rhizobium sp. strain NGR234 regulates conjugal transfer (tra) gene expression and influences growth rate. J Bacteriol 2003, 185:809-822.

60. Bladergroen MR, Badelt K, Spaink HP: Infection-blocking genes of a symbiotic Rhizobium leguminosarum strain that are involved in temperature-dependent protein secretion. Mol Plant-Microbe Interact 2003, 16:53-64.

61. Wilson K: Preparation of genomic DNA from bacteria. In Current Protocols in Molecular Biology. Volume 1. Edited by Ausubel FM, Brent R, Kingston RE, Moore DD, Seidman JG, Smith JA, Struhl K. New York: John Wiley \& Sons Inc; 1994:2.4.1-2.4.5.

62. Hyatt D, Chen G, LoCascio P, Land M, Larimer F, Hauser L: Prodigal: prokaryotic gene recognition and translation initiation site identification. BMC Bioinformatics 2010, 11:119.

63. Lowe TM, Eddy SR: tRNAscan-SE: A program for improved detection of transfer RNA genes in genomic sequence. Nucleic Acids Res 1997, 25:955-964.

64. Lagesen K, Hallin P, Rødland EA, Stærfeldt H, Rognes T, Ussery DW: RNAmmer: consistent and rapid annotation of ribosomal RNA genes. Nucleic Acids Res 2007, 35:3100-3108.

65. Rutherford K, Parkhill J, Crook J, Horsnell T, Rice P, Rajandream MA, Barrell B: Artemis: sequence visualization and annotation. Bioinformatics 2000, 16:944-945.

66. Darling AE, Mau B, Perna NT: ProgressiveMauve: multiple genome alignment with gene gain, loss and rearrangement. PLOS One 2010, 5:e11147.

67. Tatusov RL, Fedorova ND, Jackson JD, Jacobs AR, Kiryutin B, Koonin EV, Krylov DM, Mazumder R, Mekhedov SL, Nikolskaya AN, Rao BS, Smirnov S, Sverdlov AV, Vasudevan S, Wolf Yl, Yin JJ, Natale DA: The COG database: an updated version includes eukaryotes. BMC Bioinformatics 2003, 4:41.

68. Marchler-Bauer A, Zheng C, Chitsaz F, Derbyshire MK, Geer LY, Geer RC, Gonzales NR, Gwadz M, Hurwitz DI, Lanczycki CJ, Lu F, Lu S, Marchler GH, Song JS, Thanki N, Yamashita RA, Zhang D, Bryant SH: CDD: conserved domains and protein three-dimensional structure. Nucleic Acids Res 2013, 41:D348-D352.

69. Li L, Stoeckert CJ, Roos DS: OrthoMCL: identification of ortholog groups for eukaryotic genomes. Genome Res 2003, 13:2178-2189.

70. Cock PJA, Antao T, Chang JT, Chapman BA, Cox CJ, Dalke A, Friedberg I, Hamelryck T, Kauff F, Wilczynski B, de Hoon MJL: Biopython: freely available Python tools for computational molecular biology and bioinformatics. Bioinformatics 2009, 25:1422-1423.

71. Krzywinski MI, Schein JE, Birol I, Connors J, Gascoyne R, Horsman D, Jones SJ, Marra MA: Circos: an information aesthetic for comparative genomics. Genome Res 2009, 19:1639-1645.

72. Camacho C, Coulouris G, Avagyan V, Ma N, Papadopoulos J, Bealer K, Madden TL: BLAST+: architecture and applications. BMC Bioinformatics 2009, 10:421.

73. Carver TJ, Rutherford KM, Berriman M, Rajandream M, Barrell BG, Parkhill J: ACT: the Artemis comparison tool. Bioinformatics 2005, 21:3422-3423.

74. Peden JF: Analysis of codon usage. In PhD thesis. University of Nottingham, Department of Genetics: 1999.

doi:10.1186/1471-2164-15-500

Cite this article as: Österman et al:: Genome sequencing of two Neorhizobium galegae strains reveals a noeT gene responsible for the unusual acetylation of the nodulation factors. BMC Genomics 2014 15:500. 